\title{
Expression of Neuropeptide Y of GIFT Tilapia (Oreochromis sp.) in Yeast Pichia Pastoris and Its Stimulatory Effects on Food Intake and Growth
}

\author{
Guangzhong Wang, Caiyun Sun, Haoran Lin and Wensheng $\mathrm{Li}^{*}$ \\ State Key Laboratory of Biocontrol, \\ Institute of Aquatic Economic Animals and \\ Guangdong Provincial Key Laboratory for Aquatic Economic Animals, \\ School of Life Sciences, Sun Yat-Sen University, Guangzhou, \\ P. R. China
}

\section{Introduction}

Neuropeptide Y (NPY), a peptide with 36 amino acid residues which was first isolated from porcine brain (Tatemoto et al., 1982), is most highly expressed in the hypothalamic arcuate nucleus (ARC) (Lin et al., 2004). NPY is a member of the NPY family which consists of NPY, peptide YY (PYY), pancreatic polypeptide (PP) and peptide Y (PY)(Cerda-Reverter and Larhammar, 2000a). There are three NPY-related peptides were expressed in fish. They are NPY, peptide YY and peptide Y(Cerda-Reverter et al., 2000b; Sundstrom et al., 2008). Currently, NPY peptides or cDNA sequences have been obtained from many fish species including catfish, goldfish, sea bass, Atlantic cod, flounder, rainbow trout, zebrafish(Volkoff, 2006). As other low molecular weight secreted peptide, NPY is synthesized as larger peptide precursor which consists of a hydrophobic signal peptide, the mature peptide, the amidation-proteolytic site, and the carboxy-terminal extended peptide (Cerda-Reverter and Larhammar, 2000a). A partial cDNA coding for the mature peptide of NPY of tilapia (red tilapia, Oreochromis sp.) has been cloned and reported. The size of the sequence is of $192 \mathrm{bp}$, which encodes a 28 a.a. signal peptide and the 36 a.a. mature peptide, while the sequence encoding carboxy-terminal extension aside the C-terminal of mature peptide has not been reported yet (Carpio et al., 2006).

NPY is well known to be involved in many physiological functions, such as cardiovascular regulation, affective disorder, memory retention, neuroendocrine control and feeding in mammals(Pedrazzini, 2004). In fact, NPY has been considered as the most potent orexigenic peptide in mammals (Halford et al., 2004; Kalra et al., 1999; Valassi et al., 2008; Woods et al., 1998). Many studies have proved that NPY is also an important energy metabolism regulator of vertebrates. When fed with a high-carbohydrate diet; diabetic rats exhibit increased gene expression of the NPY in the hypothalamic ARC, and high-fat diet suppressed NPY expression(Chavez et al., 1998). Intraventricular administration of NPY has been shown to enhance carbohydrate and fat utilization in rats which leads to a significant 
increase in energy consumption and body weight (Kiris GA, 2007). NPY executes these functions mainly through its receptor Y1, Y2 and Y5 (Aldegunde and Mancebo, 2006; Pedrazzini et al., 2003).

NPY is one of the most highly conserved neuroendocrine peptides in vertebrates(Blomqvist et al., 1992). The NPY peptides of fish species also showed remarkable sequence homology with mammals, suggesting the similar functions of NPY in fish and mammals(CerdaReverter et al., 2000b; Sundstrom et al., 2005).As its mammalian counterpart, NPY is also a very important regulator of food intake and energy metabolism in fish(Volkoff, 2006; Volkoff et al., 2005). For example, both central and peripheral injections of mammalian or fish NPY significantly stimulated food intake in a dose dependent manner in goldfish (Lopez-Patino et al., 1999; Narnaware et al., 2000). NPY mRNA levels increased substantially a few hours before feeding goldfish, which was fed at fixed time, and then declined after feeding; Fasting could also upgrade the expression of goldfish NPY, while refeeding restored the NPY mRNA levels (Narnaware and Peter, 2001a). In addition, NPY expression was regulated by high glucose or high fat diet but not affected by the protein composition of food (Narnaware and Peter, 2002). The relationship between NPY and feeding promotion were also found in other fish species. Ventricle injection with porcine NPY significantly promoted the feeding of rainbow trout within 2-3 hours(Aldegunde and Mancebo, 2006). Brain NPY mRNA level of Atlantic cod changed before and after diet, and reached the highest level at feeding time(Kehoe and Volkoff, 2007). The short-term changes of NPY level were all related to temporary feeding regulation. Similar to mammals, NPY is a long-term energy metabolism regulation factor, long-term treatment of NPY could also significantly change the growth and feeding behavior of fish species. Recombinant protein expressed in Escherichia coli. of tilapia NPY significantly promoted the growth and food intake of tilapia by injection(Carpio et al., 2006). Immersion bath with the same prokaryotic expression of NPY three times a week significantly increased the body weight and body length of catfish (Carpio Y, 2007). NPY either administered by i.p. injection or through feed stimulated food intake as well as growth of Oreochromis niloticus (Kiris GA, 2007).

Yeast has been used in food and feed additive production for a long time. Because of the lower toxicity and higher environmental security, the yeast culture supernatant of yeast expression system for foreign genes expression can be directly used as feed of animal without purification. In addition to the advantages of molecular and genetic manipulations sharing with Saccharomyces, Pichia pastoris has higher protein expression efficiency and is easier for high-density fermentation. Moreover, as a eukaryote, Pichia pastoris has advantages in post-translational processing of higher eukaryotic expression systems such as protein processing, protein folding, and posttranslational modification that $E$. Coli. systems can not carry out, while being as easy to manipulate as E. Coli or Saccharomyces cerevisiae. It is faster, easier, and lower cost than other eukaryotic expression systems and generally gives higher expression levels. Pichia pastoris itself secrete little proteins into the culture medium, such facilities the secretion and purification of recombinant proteins. In addition, single or multiple copies of foreign genes were easy to integration into the genome of Pichia pastoris in specific site, which makes the recombinant strains to be genetically stable. These features make Pichia a very useful protein expression system suitable for industrial production (Faber et al., 1995; Romanos et al., 1992).

Treating fish with hormones or peptides to induce the food intake and growth by injections is definitely not a realistic method in aquaculture because they would require expensive, 
time-consuming injection in individual fish. To feed fish with capsules or feed containing agonists/antagonists of appetite-regulating factors might represent a viable solution (Gelineau, 2001; Volkoff et al., 2010). Previous experiments have shown that trout fed with CCK antagonists eat significantly more than their mean daily intake on the other days of the experiment (Gelineau, 2001). Tilapia, commonly known as the African carp, belongs to Perciformes, Perciformes Suborder, Cichlidae. Now, tilapia is one of the most important fish species used in aquaculture in the world. Because of its low cost, tilapia has been thought as the 21st century protein for poor people. In the present study, under purpose of developing new environmental friendly feed additives for fish, we isolated the ORF of NPY from GIFT tilapia and established the Pichia strains of pPICZaA-TiNPY1-X-33 and pPICZaA-TiNPY2X-33 to express recombinant NPY proteins. Administration of the purified NPY to GIFT tilapia showed that long-term treatment of the recombinant peptide can stimulate food intake, promote growth and reduce feed conversion ratio. Moreover, this recombinant peptide obviously stimulated pituitary GH mRNA expression, while inhibit NPY and orexin mRNA expressions in hypothalamus.

\section{Material and methods}

\subsection{Animals}

All fish used in the present experiment are GIFT Strain tilapia (Oreochromis niloticus), and were obtained from local Panyu tilapia breeding fishery of Guangzhou, China. A male tilapia with body weight of $1.5 \mathrm{~kg}$ was used for molecular cloning of NPY cDNA. Juvenile fish with the body weight ranging from 65 to $80 \mathrm{~g}$ were selected for NPY feeding experiments. Since the tilapia at this stage was "prepubertal" and sexual dimorphism was not apparent, fish of mixed sexes were used for in vivo study. All fish were kept alive in well aerated freshwater under a 12L:12D photoperiod at 26 to $28^{\circ} \mathrm{C}$. Fish for feeding experiment were cultured in a 150L tank with the density of 12 fish per tank and were acclimated to a constant flow of filtered water for two weeks before the feeding experiment. During the acclimation period, all fish were fed with normal extruded floating pellets twice a day. After finish the experiment, all fish were sacrificed by anesthesia in $0.05 \%$ MS 222 (Sigma, St. Louis, MO) followed by spinosectomy according to the regulation of animal use at Sun Yat-Sen University.

\subsection{Reagents and test substrates}

TRIzol reagent, DNAse I, SuperScript II, T/A clone TM PCR Product Cloning Kit, Platinum Taq DNA Polymerase, Zeocin, and Real-time PCR Master Mix (SYBR Green) were purchased from Invitrogen (Carlsbad, CA). E.Z.N.A Gel Extraction Kit and E.Z.N.A Plasmid Extraction Kit were obtained from Omega Bio-Tek (USA). Anti-Neuropeptide Y Rabbit pAb was purchased from Calbiochem (U.S.A). Sheep anti-rabbit secondary antibody IgG-HRP was purchased from Boster Biological Engineering Co., Ltd., (China). His $\bullet$ Bind Columns was bought from Novagen (USA). Trpton, Yeast extract and Dextrose were purchased from OXIOID (Britain). The membrane of PVDF $(0.2 \mu \mathrm{m})$ was obtained from Pall life sciences (U.S.A). Protein Marker is BIO-RAD kaleidoscope Prestained Standards.

\subsection{Molecular cloning of GIFT tilapia NPY}

Specific primers for amplification of tilapia NPY cDNA were designed based on the reported NPY sequence of red tilapia (GenBank Accession No. AY779047). The forward 
primer was F1 (5'-ATGCATCCTAACTTGGTGAGC-3') and the reverse primer was R1 (5'GGCCACGCGTCGACTAGTAC-3', AUAP). PCR was performed using the RT sample prepared from the hypothalamus as the template to pull out GIFT NPY cDNA. Briefly, total RNA was extracted from the hypothalamus of GIFT tilapia using TRIzol@reagent method. $1 \mu \mathrm{g}$ total RNA was reverse transcribed to first strand cDNA by SuperScript First-Strand Synthesis System for RT-PCR (Invitrogen) and Oligo(dT)12-18 primer (Invitrogen Adapter Primer). $5 \mu$ l of the above $20 \mu l$ reverse transcription reaction mixture was used to amplify a NPY fragment with the size of $650 \mathrm{bp}$, which include the open reading frame (ORF) and the $3^{\prime}$ untranslation region. The total volume of PCR reaction is $100 \mu l$ containing with $0.5 \mu \mathrm{l}$ Platinum Taq DNA Polymerase and the corresponding PCR buffer, $200 \mu \mathrm{M}$ of each dNTP, $30 \mu \mathrm{M} \mathrm{MgCl} 2$ and 200 pmole of F1 and AUAP primers. PCR reactions were conducted for 36 cycles with the denaturation at $94{ }^{\circ} \mathrm{C}$ for $15 \mathrm{sec}$, annealing at $53^{\circ} \mathrm{C}$ for $15 \mathrm{sec}$ and extension at $72^{\circ} \mathrm{C}$ for $1 \mathrm{~min}$. The PCR products were size-fractionated in $1.5 \%$ agarose gel and purified by using E.Z.N.A® Gel Extraction Kit. The purified PCR product was then ligated into cloning $\mathrm{T}$ plasmid vector ( $\mathrm{pTZ}$ 57R/T plasmid vector). The recombinant $\mathrm{pTZ57R/T}$ vector was transformed into DH5a (Escherichia coli), after screening and identification, plasmids of positive colonies were extracted using E.Z.N.A ${ }^{\circledR}$ Plasmid Extraction Kit and sequenced using M13F primer.

\subsection{Construction of pPICZaA-TiNPY1and pPICZaA-TiNPY2 expression vectors}

Three gene specific primers for amplification of the mature peptide of tilapia NPY were designed based on the sequence obtained to establish two different expression vectors. A forward primer (F2: 5'-CGGCCTCGAGAAAAGAGAGGCTGAAGCTTACCCAGTGAA ACCA-3') contains an Xho I site and the sequence encoding partial signal peptide which could be digested by Xho I on yeast secretory expression vector pPICZaA(Invitrogen). The reverse primers were R2 (5'-TGCTCTAGATACCTCTGTCTTGT-3') which contains an Xba I site and R3 (5'-TGATCTAGATCAATGATGATGATGATGATGATACCTCTGTCTTGT-3'). Besides the Xba I site, R3 also contains the sequence encoding $6 \times$ his tag and a stop codon. Using the NPY cDNA we obtained as template, two fragments with the size of $201 \mathrm{bp}$ (NPY1) and 226bp (NPY2) were amplified by using primer pairs of F2/R2 and F2/R3, respectively. PCR reactions were conducted for 36 cycles with the denaturation at $94{ }^{\circ} \mathrm{C}$ for $15 \mathrm{sec}$, annealing at $65^{\circ} \mathrm{C}$ for $15 \mathrm{sec}$ and extension at $72^{\circ} \mathrm{C}$ for $30 \mathrm{sec}$. The PCR products were size-fractionated in 1.5\% agarose gel and purified by using E.Z.N.A® Gel Extraction Kit. The purified PCR product and Pichia pastoris expression vector pPICZaA were digested by Xho I and Xba I, respectively. After purification, the digested PCR products were ligated with the linearized $\mathrm{pPICZaA}$. After sequencing confirmation, two recombinant expression vectors, pPICZaA-TiNPY1 and pPICZaA-TiNPY2, were established. The NPY gene of interest is cloned in frame with a C-terminal peptide containing the c-myc epitope and a polyhistidine $(6 \times$ His) tag as in pPICZaA- TiNPY1, or with only the polyhistidine $(6 \times$ His) tag as in pPICZaA- TiNPY2. The recombinant NPY proteins are expressed as fusions to an Nterminal signal peptide, a-factor secretion signal of the Saccharomyces cerevisiae. Both vectors would give high expression level of the interest gene in Pichia pastoris when induced by methanol.

\subsection{Establishment of Pichia X-33 strains of pPICZaA-TiNPY1 and pPICZaA-TiNPY2}

The competent cells of Pichia X-33 strain were prepared according to the manual of the Easyselect ${ }^{\mathrm{TM}}$ Pichia Expression Kit (Invitrogen). Two recombinant expression vectors of 
pPICZaA-TiNPY1 and pPICZaA-TiNPY2 were linearized by the digestion of PmeI (NEB) within the 5'AOX 1 region and then transformed into the competent cell of Pichia X-33 by electroporation. The linearized pPICZaA-TiNPY1 or pPICZaA-TiNPY2 was directly integrated within the $5^{\prime}$ AOX1 region of Pichia host genome (Pichia X-33 strain purchased from Invitrogen) by gene insertion. The two transformation mixtures were respectively spread onto YPDS plates (Yeast Extract Peptone Dextrose Medium), which contained 1\% yeast extract, $2 \%$ peptone, $2 \%$ dextrose (glucose), $1 \mathrm{M}$ sorbitol, $2 \%$ agar and $200 \mu \mathrm{g} / \mathrm{ml}$ Zeocin $^{\mathrm{TM}}$ (or $100 \mu \mathrm{g} / \mathrm{ml}$ Zeocin, and then screening on 200/500/1000 $\mu \mathrm{g} / \mathrm{ml}$ Zeocin YPDS for multi-copy integrants). These plates then were incubated at $28-30^{\circ} \mathrm{C}$ for about 4 days until the positive single colonies of Pichia X-33 were observed. In a parallel study, the PICZaA blank vectors were introduced into the competent cells of Pichia X-33 strain and which acts as a negative control. At this point, two recombinant Pichia X-33 strains were constructed, they were pPICZaA-TiNPY1-X-33 and pPICZaA-TiNPY2-X-33, which could express recombinant TiNPY1 (tilapia NPY mature peptide with a C-terminal peptide containing the c-myc epitope and $6 \times$ His tag, total 58 a.a.) or TiNPY2 (tilapia NPY mature peptide with only the $6 \times$ His tag, total 42 a.a.) respectively.

\subsection{Induction of recombinant protein expression of TiNPY1 and TiNPY2}

Single colonies of genetically engineered Pichia pastoris strains pPICZaA-Ti NPY1-X-33, pPICZaA-TiNPY2-X-33 and pPICZaA-X-33 (as a negative control $\mathrm{NC}_{0}$ ) were picked and cultured in $5 \mathrm{ml}$ BMGY medium(1\% yeast extract, $2 \%$ peptone, $100 \mathrm{mM}$ potassium phosphate, $\mathrm{pH} 6.0,1.34 \% \mathrm{YNB}, 4 \times 10^{-5} \%$ biotin, $1 \%$ glycerol) at $30^{\circ} \mathrm{C}$ in a shaking incubator (250rpm)for $24 \mathrm{~h}$. When the OD600 of the culture is within the range from 4.0 to $6.0,200 \mu \mathrm{l}$ culture of each colony was stocked in $15 \%$ glycerol at $-80{ }^{\circ} \mathrm{C}$.

The remained cells were harvested by centrifuging at $1500 \mathrm{~g}$ for 5 minutes at $4^{\circ} \mathrm{C}$. Discard the supernatant and resuspend the cell pellet into BMMY medium (1\% yeast extract, $2 \%$ peptone, $100 \mathrm{mM}$ potassium phosphate, $\mathrm{pH} 6.0,1.34 \% \mathrm{YNB}, 4 \times 10-5 \%$ biotin, $0.5 \%$ methanol) to induce NPY protein expression at $28-30^{\circ} \mathrm{C}$ with the shaking speed of $250 \mathrm{rpm}$. The media of one of PICZaA-TiNPY1-X-33 or pPICZaA-TiNPY2-X-33 was not be replaced and maintained in BMGY medium to act as negative control of $\mathrm{NC}_{1}$ and $\mathrm{NC}_{2}$.

$1 \mathrm{ml}$ cultures of each tube were sampled and cultured in BMMY medium with $0.5 \%$ methanol to maintain induction every 24 hours. In a parallel study, instead of replacing the culture medium, one culture of PICZaA-TiNPY1-X-33 or pPICZaA-TiNPY2-X-33 remained to be cultured in BMGY and act as negative control of $\mathrm{NC}_{1}$ and $\mathrm{NC}_{2}$. Sampled cultures were centrifuged to collect supernatant respectively, and the supernatants were stored at $-20^{\circ} \mathrm{C}$ or directly concentrated and analyzed by Tricine-SDS-PAGE gel and western blot. The expressed recombinant protein by pPICZaA-TiNPY1-X-33 and pPICZaA-TiNPY2-X-33 were named TiNPY1 and TiNPY2.

\subsection{Analysis of recombinant NPY proteins by Tricine-SDS-PAGE and western blot}

The harvested supernatants with recombinant proteins were concentrated and analyzed by Tricine-SDS-PAGE gel electrophoresis according to the standard procedure. Samples were first run under $50 \mathrm{~V}$ for $1 \mathrm{~h}$ and then change the voltage to $75 \mathrm{~V}$ for another $1 \mathrm{~h}$. After electrophoresis, the gel was stained with Coomassie blue for $20 \mathrm{~min}$, and then analyzed whether the recombinant proteins TiNPY1 (with a molecular weight about 6.9KD) and TiNPY2 (with a molecular weight about 5.1KD) were present or not. 
After analysis by Tricine- SDS-PAGE gel electrophoresis, samples induced with different time were analyzed by western blot. After separation by Tricine-SDS-PAGE gel electrophoresis, proteins were electro-transferred from the gel to a PVDF membrane. The recombinant protein was recognized with a rabbit polyclonal antibody against porcine NPY (purchased from Calbiochem Corporation, USA) with a dilution of 1:1000, which was recognized by sheep anti-rabbit secondary antibody IgG-HRP (purchased from Boster Biological Engineering Co., Ltd., China). Western blot results were detected by chemiluminescence detection system.

\subsection{Expression kinetics of NPY}

Since the protein banding patterns of TiNPY1 and TiNPY2 in supernatant were varying with different induction time, it is necessary to study the kinetics of NPY expression. In the present study, NPY1 expression was taken as a model to study the relationship of induction time and TiNPY1 protein expression pattern. Four colonies of pPICZaA-TiNPY1-X-33 were used to express recombinant protein of NPY. The supernatants were harvested for TricineSDS-PAGE gel electrophoresis and western blot at the time point of $12 \mathrm{~h}, 24 \mathrm{~h}$ and $48 \mathrm{~h}$ after $0.5 \%$ methanol induction.

\subsection{Purification of the recombinant NPY proteins}

Since Recombinant protein TiNPY1 and TiNPY2 were conjugated with $6 \times$ His tag, His $\bullet$ Bind Column (NOVAGEN) could be used to purify these proteins. $\mathrm{pH}$ of supernatants of methanol-induced culture were adjusted to 7.9 by $\mathrm{NaOH}$ and then all samples were loaded into the His $\bullet$ Bind Column which was equilibrated with $15 \mathrm{ml}$ binding buffer $(0.5 \mathrm{M} \mathrm{NaCl}$, $20 \mathrm{mM}$ Tris- $\mathrm{HCl}, 5 \mathrm{mM}$ imidazole, $\mathrm{pH} 7.9$ ) before use. The column was washed by $10 \mathrm{ml}$ wash buffer $(0.5 \mathrm{M} \mathrm{NaCl}, 60 \mathrm{mM}$ imidazole, $20 \mathrm{mM}$ Tris- $\mathrm{HCl}, \mathrm{pH} 7.9)$ to remove unbound proteins. The recombinant protein was eluted by elute buffer with different concentration of imidazole (150/250/500mM imidazole, 0.5M NaCl, 20mM Tris-HCl, pH 7.9).Each fraction was eluted with one milliliter elution. Tricine-SDS-PAGE gel electrophoresis was conducted to analyze the purification with comparisons of before and after purified supernatants.

\subsection{Sequencing of N-terminal amino acid of NPY}

The purified TiNPY1 protein bands were electro-transferred from the gel to a PVDF membrane, and the sequencing of N-terminal amino acid of TiNPY1 was performed by using Sequencing instrument PROCISE491 (Applied Biosystemes Company, USA) with EDMEN degradation method.

\subsection{Diet preparation and feeding experiment with juvenile tilapia}

Five different diets for feeding experiments were prepared by homogeneously spraying three kinds of yeast culture supernatants directly onto the surface of ordinary commercial extruded floating feed. The concentrations of the recombinant proteins of NPY1 in three diets are $0.15,0.3$ and $0.6 \mu \mathrm{g}$ TiNPY1/g feed, respectively. A diet contains the recombinant protein TiNPY2 to a level of $0.3 \mu \mathrm{g}$ TiNPY2/g feed. A diet without any addition of recombinant protein acts as a negative control feed. All diets were stored at $-20^{\circ} \mathrm{C}$ before use.

After finishing two week's acclimation, 180 fish of GIFT Strain tilapia, with a body weight ranging from 60 to $80 \mathrm{~g}(73.09 \pm 3.58 \mathrm{~g})$ and length ranging from 12.0 to $14.0 \mathrm{~cm}$ were randomly 
assigned to 15 aquariums and 12 fish were cultured in an aquarium. All 15 aquariums were divided into five groups with three aquariums (three replicates, $n=12$ ) per group. One group was fed with a kind of diet. Group1, 2, 3 were fed with diets containing 0.15, 0.3 and 0.6 $\mu \mathrm{g}$ TiNPY1/g feed, respectively. Group 4 took the control feed and group 5 was fed with $0.3 \mu \mathrm{g}$ TiNPY2/g feed. The feeding experiment was taken for 50 days. All fishes were cultured at $28{ }^{\circ} \mathrm{C}$ under a $12 \mathrm{~L}$ : $12 \mathrm{D}$ photoperiod. Fish were fed with the pellet feed two times daily to satiation at 09:00 and 18:00 (animals didn't take any feed within one hour after the beginning of feeding). The remained feeds were removed one hour after each feeding operation and dried to calculate food intake of fish in each tank. Every 10 days, all fish in each aquarium were caught and dried briefly with towel, and then the weight for each fish was measured. The fish were not fed with anything within $24 \mathrm{~h}$ before measurement. The body length of each fish was also measured at the beginning and the end of feed experiment. The whole feeding experiment lasted for 50 days.

After finishing the feeding experiment, all fish were sacrificed and their tissues were removed for the following experiments: pituitaries and hypothalamuses were used for RNA extraction and RT-PCR; Livers and all guts were weighed to determine the hepatosomatic index (HSI) and visceral body weight, which were calculated as $100 \times$ liver weight/body weight and 100× gut weight/body weight. The mRNA expression of growth hormone $(\mathrm{GH})$, NPY and orexin were detected by using Real-time PCR technique. Fish dorsal white muscle of each group was sampled for moisture, crude protein and total lipid content were analyzed according to the method of Kjeldahl (AOAC, 1984) and Soxhlet extraction method, respectively.

\subsection{Data transformation and statistical analysis}

For feeding experiment, feeding conversion ratio (SGR) was calculated in terms of the number of grams of feed that are used to produce one gram of whole fish. For real-time PCR measurement of GH, NPY and orexin mRNA, $18 \mathrm{~S}$ mRNA acts as an internal control to normalized with mRNA of the target gene. Data were presented as means \pm SEM and analyzed with one-way ANOVA followed by Fisher's Least Significance Difference (LSD) test. Differences between groups were considered as significant at $\mathrm{P}<0.05$.

\section{Results}

\subsection{Molecular cloning of cDNA encoding the NPY of GIFT tilapia and construction of the expression vectors of pPICZaA-TiNPY1and pPICZaA-TiNPY2}

The ORF and 3' untranslation region (UTR) of GIFT tilapia NPY was cloned (Fig.1). The partial cDNA of NPY is 659bp in size with a 359bp 3'UTR and 300bp ORF encoding a 99 a.a. precursor protein. A putative signal peptide of 28 a.a. is located in the N-terminal of NPY. And a 36 a.a. mature peptide is highly conserved with that of human NPY (89\% identity). The remained 35 a.a. is the C-terminal of NPY.

Two different expression vectors of GIFT tilapia were established and they were named as pPICZaA-TiNPY1 and pPICZaA-TiNPY2 (Fig.2) The insert size of pPICZaA-TiNP1 is 201bp which encodes 36 a.a. NPY mature peptide and a C-terminal peptide with a c-myc epitope and a polyhistidine $(6 \times$ His) tag. The insert size of pPICZaA-TiNPY2 is $226 \mathrm{bp}$ which encodes NPY mature peptide and a polyhistidine $(6 \times \mathrm{His})$ tag. 
ATGCATCCTAACTTGGTGAGCTGGCTGGGGACTCTGGGGTTCCTGCTGTGGGCGCTGGTC 60

$\begin{array}{lllllllllllllllllllll}M & H & P & N & L & V & S & W & L & G & T & L & G & F & L & L & W & A & L & V\end{array}$

TGCTTGGGCGCCTTGACGGAGGCATACCCAGTGAAACCAGAGAACCCCGGGGAGGACGCC 120

$\begin{array}{lllllllllllllllllllll}\text { C } & \text { L } & \text { G } & \text { A } & \text { L } & \text { T } & \text { E } & \text { A } & \text { Y } & \text { P } & \text { V } & \text { K } & \text { P } & \text { E } & \text { N } & \text { P } & \text { G } & \text { E } & \text { D } & \text { A }\end{array}$

CCCGCGGAGGAGCTGGCCAAGTACTACTCAGCCCTGAGACATTACATCAACCTCATTACA 180

$\begin{array}{llllllllllllllllllll}\mathbf{P} & \mathbf{A} & \mathbf{E} & \mathbf{E} & \mathbf{L} & \mathbf{A} & \mathbf{K} & \mathbf{Y} & \mathbf{Y} & \mathbf{S} & \mathbf{A} & \mathbf{L} & \mathbf{R} & \mathbf{H} & \mathbf{Y} & \mathbf{I} & \mathbf{N} & \mathbf{L} & \mathbf{I} & \mathbf{T}\end{array}$

AGACAGAGGTATGGGAAGAGATCCAGTCCTGAGATTCTGGACACACTGGTCTCAGAGCTG 240

$\begin{array}{llllllllllllllllllll}\mathbf{R} & \mathbf{Q} & \mathbf{R} & \mathbf{Y} & \mathrm{G} & \mathrm{K} & \mathrm{R} & \mathrm{S} & \mathrm{S} & \mathrm{P} & \mathrm{E} & \mathrm{I} & \mathrm{L} & \mathrm{D} & \mathrm{T} & \mathrm{L} & \mathrm{V} & \mathrm{S} & \mathrm{E} & \mathrm{L}\end{array}$

CTGCTGAAGGAAAGCACAGACACGCTTCCACAGTCAAGATATGACCCATCAATGTGGTGA 300

$\begin{array}{llllllllllllllllllll}\mathrm{L} & \mathrm{L} & \mathrm{K} & \mathrm{E} & \mathrm{S} & \mathrm{T} & \mathrm{D} & \mathrm{T} & \mathrm{L} & \mathrm{P} & \mathrm{Q} & \mathrm{S} & \mathrm{R} & \mathrm{Y} & \mathrm{D} & \mathrm{P} & \mathrm{S} & \mathrm{M} & \mathrm{W} & \star\end{array}$

TGCTGCCATCACTCTCGTCTCGCTCACTGCTGTCCCGCCAGCGCTGACATTCTGACCTCT 360

ACACGTCCGTCACTTACCTCCTACACCAAACGAACACCACGCCTCTGCCCTCCTTTCGCC 420

TCCATGAGCCGCAACGTATATATCCAACCCCTCTTCCTTACGCATCAGCCACACCCAACA 480

CTGCTTGAAGTCTGTGCCATAAAACTGTAAATACTTTATTCTGAGTCGTCATCTGTGCAA 540

CATGATCGTAAAGTGGAGGAGGGGGGGTCTGCTGATTGTATTGTATATTTGTGCTATTAA 600

$\begin{array}{ll} & 630\end{array}$

Fig. 1. Nucleotides and deduced amino acid (a.a.) sequence of tilapia NPY. The a.a. sequence underlined with the black dotted line is the predicted signal peptide. The mature peptide of NPY is highlight in grey box.

pPICZaA-TiNPY1:

5' -CTCGAGAAAAGAGAGGCTGAAGCT

TACCCAGTGAAACCAGAGAACCCCGGGGAGGACGCCCCCGCGGAGGAGCTGGCC $\begin{array}{llllllllllllllllll}\text { Y } & P & \text { V } & \text { K } & \text { P } & \text { E } & \text { N } & \text { P } & \text { G } & \text { E } & \text { D } & \text { A } & \text { P } & \text { A } & \text { E } & \text { E } & \text { L } & \text { A }\end{array}$

$\mathbf{A}$

AAGTACTACTCAGCCCTGAGACATTACATCAACCTCATTACAAGACAGAGGTATCTA $\begin{array}{lllllllllllllllllllll}\text { K } & \text { Y } & \text { Y } & \text { S } & \text { A } & \text { L } & \text { R } & \text { H } & \text { Y } & \text { I } & \text { N } & \text { L } & \text { I } & \text { T } & \text { R } & \text { Q } & \text { R } & \text { Y } & \text { L }\end{array}$ GAACAAAAACTCATCTCAGAAGAGGATCTGAATAGCGCCGTCGACCATCATCATCAT $\begin{array}{lllllllllllllllllll}\mathbf{E} & \mathbf{Q} & \mathbf{K} & \mathbf{L} & \mathbf{I} & \mathbf{S} & \mathbf{E} & \mathbf{E} & \mathbf{D} & \mathbf{L} & \mathrm{N} & \mathrm{S} & \mathrm{A} & \mathrm{V} & \mathrm{D} & \mathbf{H} & \mathbf{H} & \mathbf{H} & \mathbf{H}\end{array}$ CATCATTGA-3'

H $\quad$ H $\star$

pPICZaA-TiNPY2: $\quad 5$ '-CTCGAGAAAAGAGAGGCTGAAGCT TACCCAGTGAAACCAGAGAACCCCGGGGAGGACGCCCCCGCGGAGGAGCTGGCC $\begin{array}{llllllllllllllllll}\text { Y } & \mathrm{P} & \mathrm{V} & \mathrm{K} & \mathrm{P} & \mathrm{E} & \mathrm{N} & \mathrm{P} & \mathrm{G} & \mathrm{E} & \mathrm{D} & \mathrm{A} & \mathrm{P} & \mathrm{A} & \mathrm{E} & \mathrm{E} & \mathrm{L} & \text { A }\end{array}$

B AAGTACTACTCAGCCCTGAGACATTACATCAACCTCATTACAAGACAGAGGTATCAT $\begin{array}{lllllllllllllllllllll}\text { K } & \text { Y } & \text { Y } & \text { S } & \text { A } & \text { L } & \text { R } & \text { H } & \text { Y } & \text { I } & \text { N } & \text { L } & \text { I } & \text { T } & \text { R } & \text { Q } & \text { R } & \text { Y } & \text { H }\end{array}$ CATCATCATCATCATTGATCTAGATCAACAAAAACTCATCTCAGAAGAGGATCTGAA $\begin{array}{llllllllllll}\mathbf{H} & \mathbf{H} & \mathbf{H} & \mathbf{H} & \mathbf{H} & \star\end{array}$ TAGCGCCGTCGACCATCATCATCATCATCATTGA-3'

Fig. 2. Nucleotide and deduced amino acid sequences of NPY1 (A) and NPY2 (B) that were subcloned into pPICZaA to establish the expression vectors. The mature peptide of NPY is highlight in grey box, and the " $\mathrm{H}$ " in bold are 6XHis tags. 


\subsection{Establishment of the recombinant Pichia X-33 stains of PICZ $\alpha A-T i N P Y 1$ and pPICZaA-TiNPY2}

To get the high-yield strains of recombinant TiNPY1 and TiNPY2 produced by engineered Pichia pastoris, pPICZaA-TiNPY1 and pPICZaA-TiNPY2 were introduced into Pichia X-33 strains by electroporation, respectively. After selection by using different concentration of Zeocin, the strains with the integration of TiNPY1, TiNPY2 and pPICzaA blank vector into the genome of Pichia pastoris X-33(Fig.3) were selected for our study. These strains with high Zeocin-resistance were named as pPICZaA-TiNPY1-X-33, pPICZaA-TiNPY2-X-33 and pPICZaA-X-33. pPICZaA-TiNPY1-X-33 can express a 58 a.a. peptide with 36 a.a. NPY mature peptide and a C-terminal peptide containing the c-myc epitope and $6 \times$ His tag, while the strain of pPICZaA-TiNPY1-X-33 can express a 42 a.a. peptide with NPY mature peptide and a $6 \times$ His tag.

\subsection{Expression of recombinant NPY1 and NPY2 in Pichia X-33 stains}

To study the expression pattern of recombinant NPY1 and NPY2 in Pichia pastoris, pPICZaA-TiNPY1-X-33, pPICZaA-TiNPY2-X-33 were induced by using 5\% methanol with the time points of $24 \mathrm{~h}, 48 \mathrm{~h}$ and $72 \mathrm{~h}$. The results of SDS-PAGE and Commassie blue staining of recombinant NPY at different times of methanol induction showed that six clones of each recombinant strain of pPICZaA-TiNPY1-X-33 and pPICZaA-TiNPY2-X-33 could express tilapia TiNPY1and TiNPY2, respectively. For pPICZaA-TiNPY2-X-33 after $24 \mathrm{~h}$ methanol induction, in addition to a band with the size of 5-6KD was observed in all six colonies,

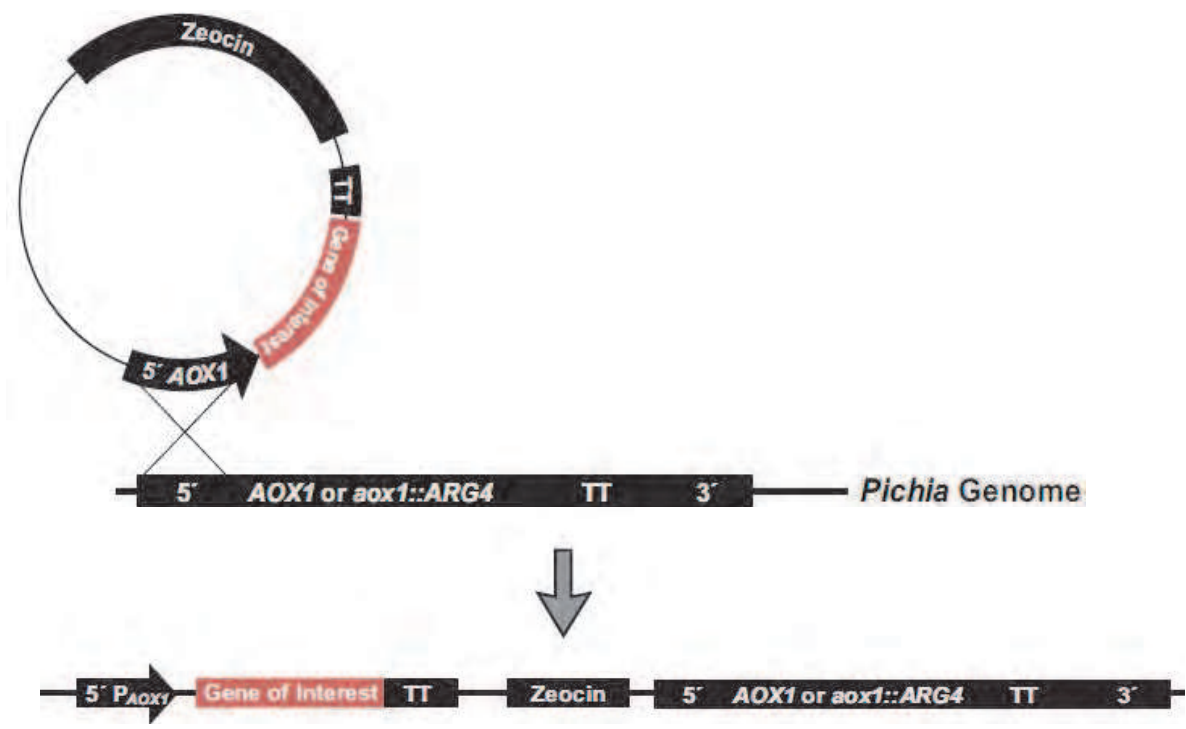

Fig. 3. Integration of TiNPY1, TiNPY2 and pPICza-A blank vector into the genome of Pichia pastoris X-33. The pPICzaA blank vector, pPICzaA-TiNPY-1 and pPICzaA-TiNPY-2 were transformed into Pichia pastoris X-33 by electroporation. After selection by using different concentration of Zeocin, three colonies of Pichia pastoris X-33 with high Zeocin resistance and high copy number were obtained, namely pPICZaA-TiNPY1-X-3, pPICZaA-TiNPY2-X33 and pPICZaA-X-33. 
there is a band with the size of 6-7KD expressed in colonies 1,2,3 and 4(Fig.4). After 48h induction, the band with the size of $5-6 \mathrm{KD}$ is still appear in all six colonies, but the expression level of the band is significantly lower than that of 24 h-induction, while a band with a small size (2-4KD) was observed in all colonies(Fig.5). All bands almost disappeared except for colony 3 after methanol induction for $72 \mathrm{~h}$ (Fig.6). Among the six colonies, only colony 3 has a stable expression pattern when induced by $5 \%$ methanol for $24 \mathrm{~h}$ to $72 \mathrm{~h}$. Similar phenomenon was also observed in the strain of pPICZaA-TiNPY1-X-33. All six colonies selected expressed a peptide with the size of 7-9KD after $24 \mathrm{~h}$ induction(Fig.4), but when the induction time increased to $48 \mathrm{~h}$, the band observed is about $5-6 \mathrm{KD}$ (Fig.5) and this band is still the major band after induction for $72 \mathrm{~h}$ (Fig.6). In a parallel study, the pPICZaA $\mathrm{X}-33$ with methanol induction acts as negative control (NC0). The stains of pPICZaATiNPY1-X-33 and pPICZaA-TiNPY2-X-33 without methanol induction were also employed as negative controls (NC1 and NC2). No matter how long of the induction time, there is no band was present in the three negative controls.

Western blot was carried out to test the immunological characteristics of recombinant TiNPY1 and TiNPY2. These proteins were size-fractionated in 10\% SDS-PAGE and transblotted onto the PVDF membrane. The recombinant proteins were recognized by a

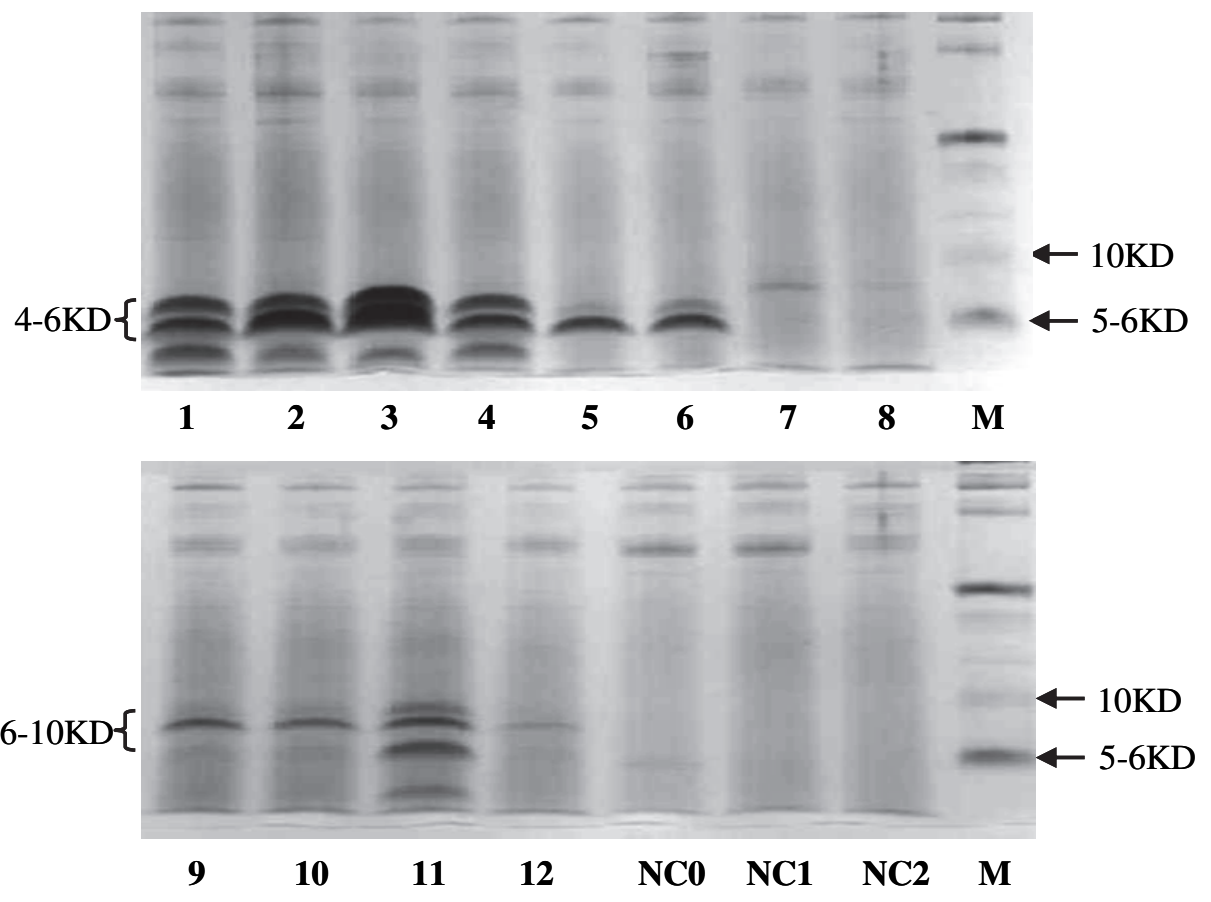

Fig. 4. SDS-PAGE detection of the expression of TiNPY1 and TiNPY2 after methanol induction for 24 hours.1-6:TiNPY2; 7-12:TiNPY1; NC0: pPICZaA-X-33 blank vector (negative control); NC1: pPICZaA-TiNPY1-X-33 without induction; NC2: pPICZaA-TiNPY2-X-33 without induction; M: protein marker. The size of TiNPY1 and TiNPY 2 is $6-9 \mathrm{KD}$ and $4-6 \mathrm{KD}$, respectively. 
rabbit polyclonal antibody against porcine NPY at a dilution 1:1000, which was recognized by sheep anti-rabbit secondary antibody IgG-HRP. $1 \mu \mathrm{g}$ of synthesized tilapia NPY with a molecular weight of $4.104 \mathrm{KD}$ was used as a positive control. The size of the NPY is smaller than both TiNPY1 and TiNPY2 because it lacks conjugated tags. The protein concentration of TiNPY1 and TiNPY2 in culture supernatants, when up-scale expressed in 1L shake-flask, were determined by scanning densitometry of dyed Tricine-SDS-PAGE gel and compared with the positive control (Fig.7,A). Western blot results showed that different from the SDSPAGE detection that all colonies selected expressed the recombinant TiNPY1, only four colonies (No.2, 3, 4 and 6) were recognized by NPY antibodies (Fig.7,B). For TiNPY-2, SDSPAGE showed that two of three colonies examined express two kinds of NPY with the molecular weight of 6-7KD and 5-6KD, while colony 3 only expressed the band with the size of 5-6KD (Fig.8,A). All these bands could be recognized by NPY antibody (Fig.8, B).

\subsection{Time course study of the recombinant protein expression of TiNPY1}

As the size and number of specific protein bands of TiNPY1 and TiNPY2 in supernatant were varying with different induction time, the expression kinetics of NPY1 was performed by inducing the expression of four pPICZaA-TiNPY1-X-33 colonies which came from the

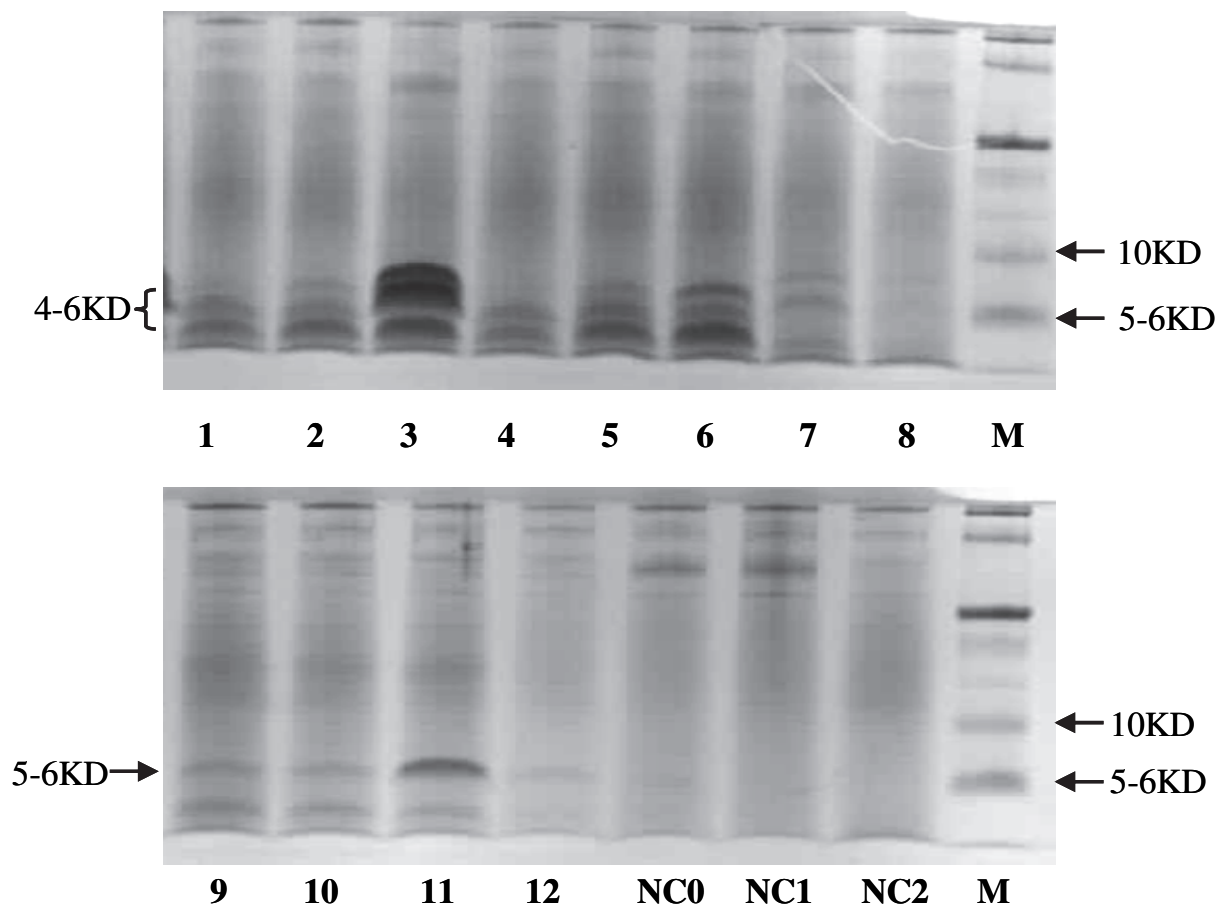

Fig. 5. SDS-PAGE detection of the expression of TiNPY1 and TiNPY2 after methanol induction for 48 hours.1-6:TiNPY2; 7-12:TiNPY1; NC0: pPICZaA-X-33 blank vector (negative control); NC1: pPICZaA-TiNPY1-X-33 without induction; NC2: pPICZaA-TiNPY2-X-33 without induction; M: protein marker. The size of TiNPY1 and TiNPY2 is 5-6KD and 4-6KD, respectively. 
same colony (Fig.4, colony 11) and could express recombinant protein TiNPY1 efficiently. Tricine-SDS-PAGE result showed that when induced by methanol for $12 \mathrm{~h}$ and $24 \mathrm{~h}$, the recombinant protein that pPICZaA-TiNPY1-X-33 expressed is about 10-12KD and 7-9KD. With the induction time increased to $48 \mathrm{~h}$, the molecular weight of TiNPY1 decreased to 67KD (Fig.9). Western blot result demonstrated that NPY antibody could only recognize the two protein bands induced by methanol for $12 \mathrm{~h}$ as well as $24 \mathrm{~h}$. While after $48 \mathrm{~h}$ induction, nothing could be observed in the membrane and two bands appeared before were missing, (Fig.10).

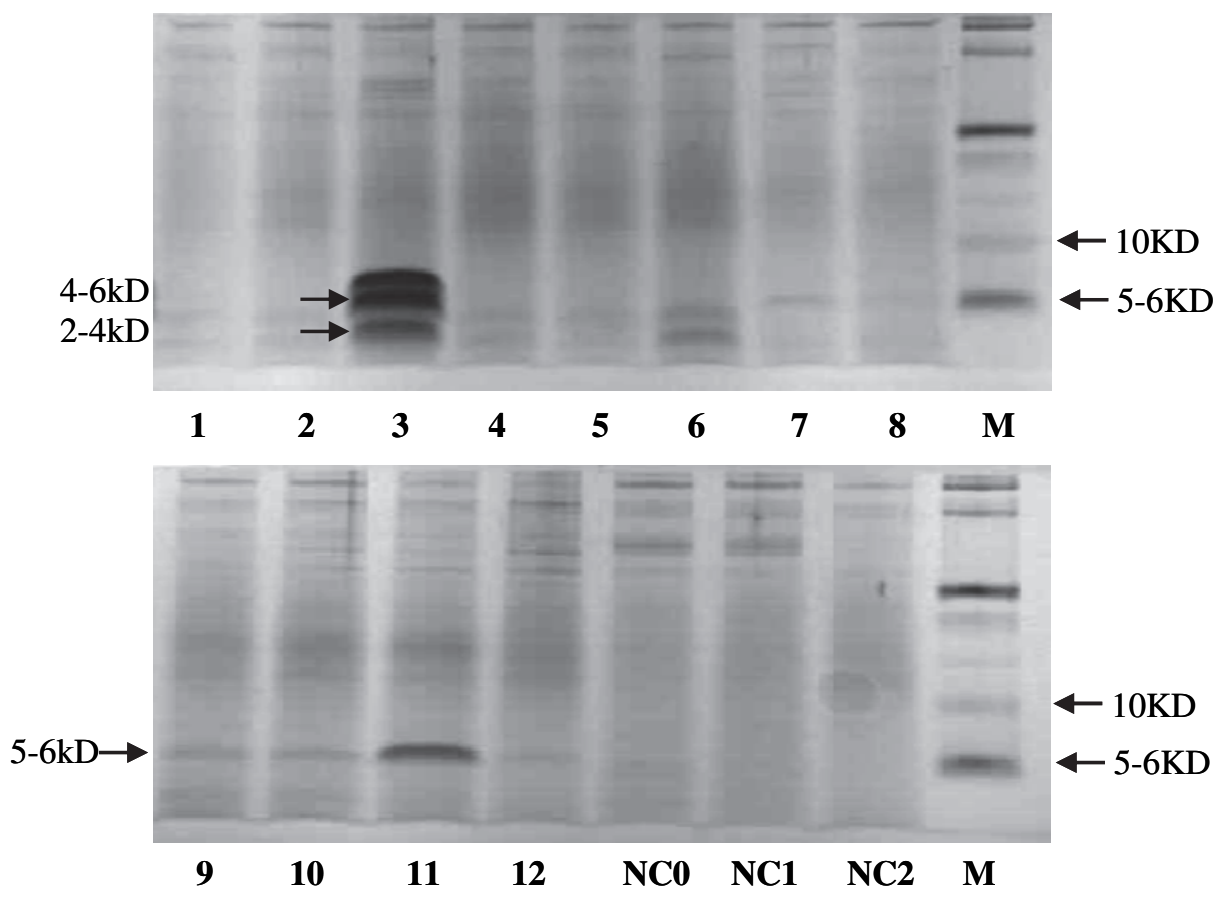

Fig. 6. SDS-PAGE detection of the expression of TiNPY1 and TiNPY2 after methanol induction for 72 hours. 1-6:TiNPY2; 7-12:TiNPY1; NC0: pPICZaA-X-33 blank vector (negative control); NC1: pPICZaA-TiNPY1-X-33 without induction; NC2: pPICZaA-TiNPY2X-33 without induction; M: protein marker. The size of TiNPY1 and TiNPY2 is 5-6KD and 24kD, 4-6KD, respectively.

\subsection{Purification of the recombinant tilapia NPY and sequencing of its $\mathrm{N}$-terminal amino acid}

As TiNPY1 and TiNPY2 were conjugated with $6 \times$ His tag, they could be purified with His $\bullet$ Bind Column by affinity chromatography. Samples from each fraction were sizefractionated by Tricine-SDS-PAGE with comparisons of supernatants before and after purification (Fig.11 and 12). The binding of the fusion recombinant proteins to the His • Bind Column (Ni-NTA column) was highly efficient as seen in Fig.11 (TiNPY1) and Fig.12 (TiNPY2). All of the three protein bands of TiNPY1 induced by methanol for 24 hours (Fig. 
11) and two bands of TiNPY2 induced for 12 hours (Fig. 12) were eluted by $150 \mathrm{mM}$ imidazole. During the process of purification of TiNPY2, wash buffer was checked after washing to confirm that there were no recombinant proteins were washed out.

Two protein bands with larger molecular weight of TiNPY1 were purified and the 1-8th amino acids of their N-terminal were sequenced by instrument PROCISE491 (Applied Biosystemes Company, USA) with EDMEN degradation method. There are three kinds of proteins with different $\mathrm{N}$-terminal a.a. (1-8th) were observed in the band with the largest molecular weight of TiNPY1. The protein with the N-terminal of N-EAYPVKPE is the major form which occupies $60-70 \%$ of TiNPY1. Proteins with the N-terminal of N-EAEAYPVK and N-YPVKPENP constitute of $20-30 \%$ and $5-10 \%$ of TiNPY1, respectively. The second band of TiNPY1 protein consists of two proteins with N-terminal of N-YPVKPENP (above 90\%) and N-VKPENPGE (minority).

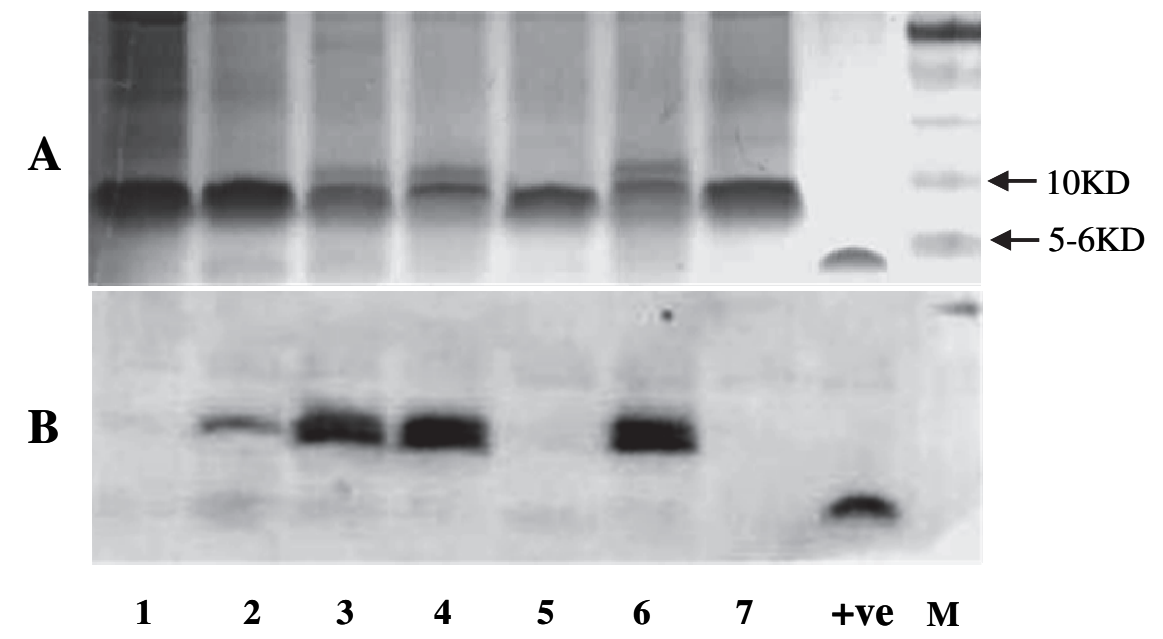

Fig. 7. SDS-PAGE to detect the expression of TiNPY1 (A) and western blot to confirm the immunological activity of recombinant TiNPY1. Samples (No.1-7) used in these experiments are recombinant TiNPY1 expressed by PICZaA-TiNPY1-X-33 after induction for different time. The synthesized tilapia NPY without His tags was used as positive control (4.104KD); M: protein marker

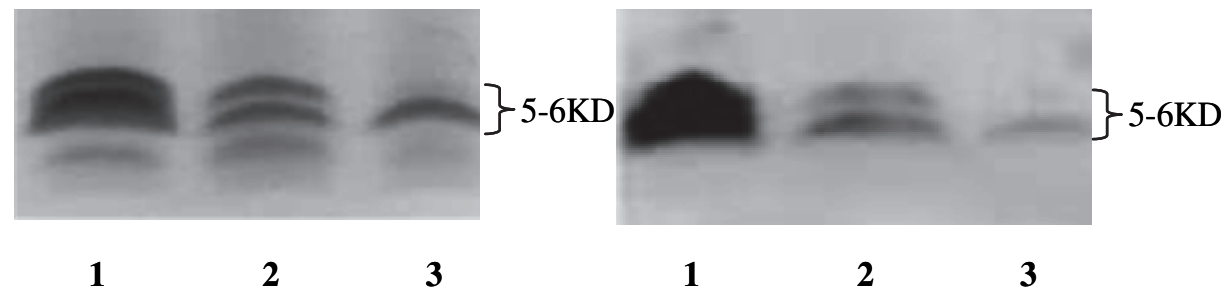

Fig. 8. SDS-PAGE to detect the expression of TiNPY2 (left) and western blot (right) to confirm the immunological activity of recombinant TiNPY2. Samples (No.1-3) used in these experiments are recombinant TiNPY2 expressed by PICZaA-TiNPY2-X-33. 

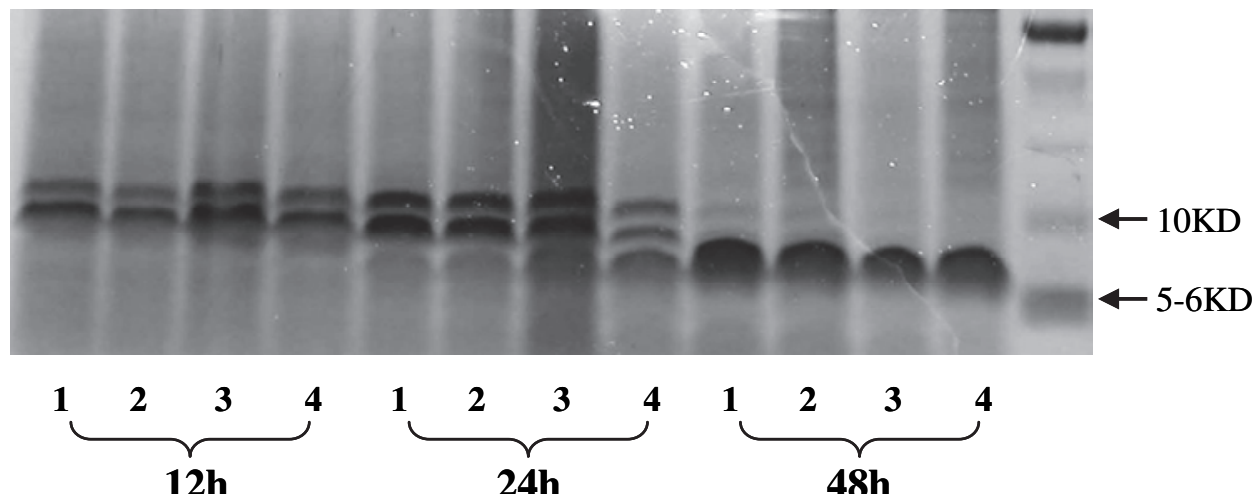

Fig. 9. Time course study of TiNPY1 expression induced by methanol. Four single colonies of pPICZaA-TiNPY1-X-33 with stable expression of TiNPY were used in the experiment. After induction of the expression by $0.5 \%$ methanol for $12 \mathrm{~h}, 24 \mathrm{~h}$ and $48 \mathrm{~h}$, the samples were harvested for SDS-PAGE.

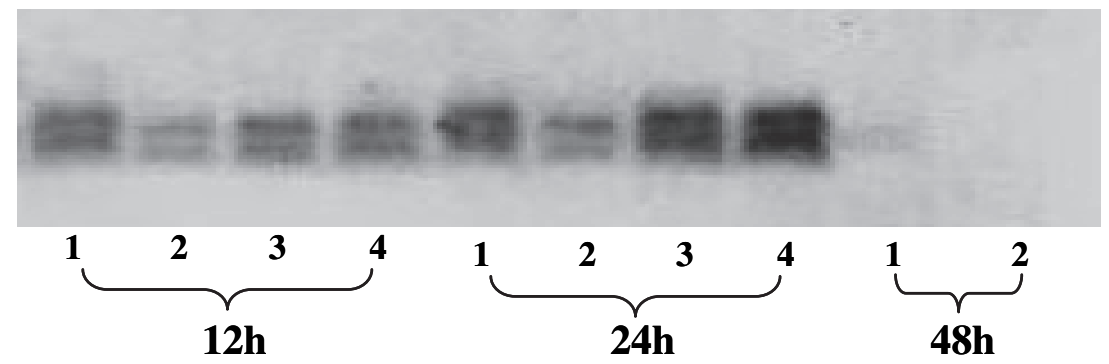

Fig. 10. Time course study of TiNPY1 expression by Western blot. The same samples used in SDS-PAGE study were used in this experiment. Two samples of $48 \mathrm{~h}$ were the sample 3 and 4 in SDS-PAGE, respectively. Only TiNPY1 expressed after $12 \mathrm{~h}$ and $24 \mathrm{~h}$ induction were recognized by polyclonal antibody of NPY.

\subsection{Effects of recombinant TiNPY on food intake and growth of the juveniles of GIFT tilapia}

The results of in vivo study showed that the recombinant proteins of NPY could significantly stimulated food intake and body growth of GIFT tilapia. Compared to the control group (group 4), the percentages of average body weight increased in the group fed with $0.15 \mu \mathrm{gTiNPY} 1 / \mathrm{g}$ feed (group 1), $0.3 \mu \mathrm{gTiNPY} 1 / \mathrm{g}$ feed (group 2) or $0.6 \mu \mathrm{gTiNPY} 1 / \mathrm{g}$ feed (group 3) were $29.65 \%, 32.11 \%$ and $12.60 \%$, respectively. And the body weight of tilapia fed with $0.3 \mu \mathrm{gTiNPY} 2 / \mathrm{g}$ feed was increased to $43.05 \%$ which gained the highest growth speed. The specific growth rates (SGR) and the final mean body lengths of all experimental groups [group $1(\mathrm{P}<0.001)$, group $2(\mathrm{P}<0.001)$, group $3(\mathrm{P}<0.05)$ and group $5(\mathrm{P}<0.001)$ ] were significantly higher than the control group (group 4 ) after 50 days (Table 1). There were no obvious difference in initial mean weight of the 5 groups, but after 50 days' experiment, the final mean weight of group 1, group 2 and group 5 were significantly higher than group 4 
by $15.31 \%(\mathrm{P}<0.001), 16.59 \%(\mathrm{P}<0.001)$ and $22.45 \%(\mathrm{P}<0.001)$, respectively. The final mean weight of group 3 was $6.29 \%$ higher than the control group but with no significant difference (Table 1 and Fig.13). The possible detrimental effects of high levels of NPY on tilapia were studied through evaluation of HSI and gut weight ratio. No significant difference was found between groups fed with recombinant tilapia NPY and control group (Table 1). In the present study, we also analyzed the contents of moisture, crude protein, total lipid and ash of the dorsal white muscle of tilapia in each groups and no significant differences were observed except for the lipid content of group 5 compared to the control $(\mathrm{P}<0.01)$ (Table 2).

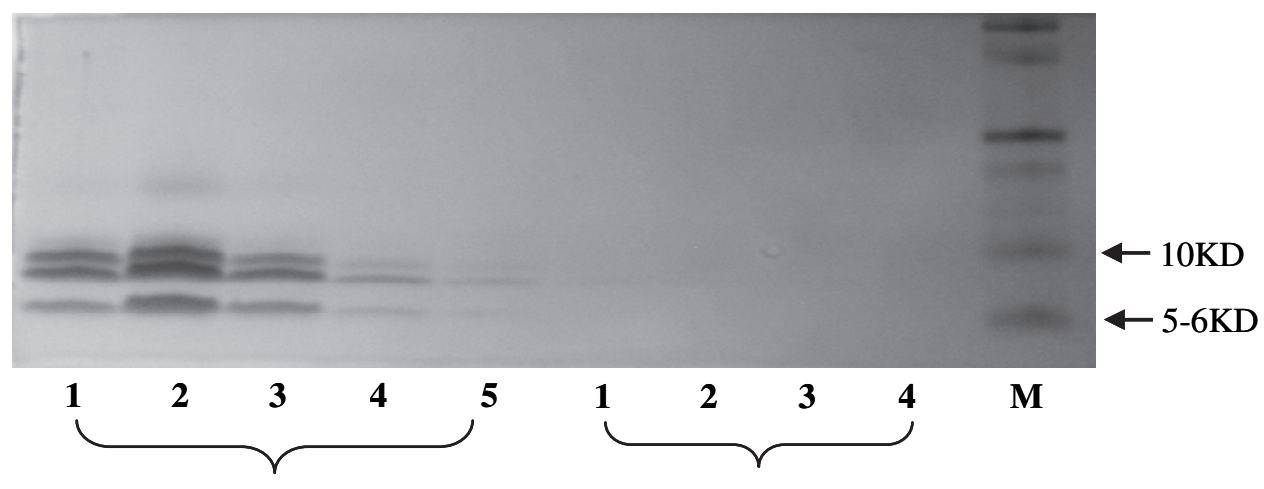

$150 \mathrm{mM}$

$250 \mathrm{mM}$

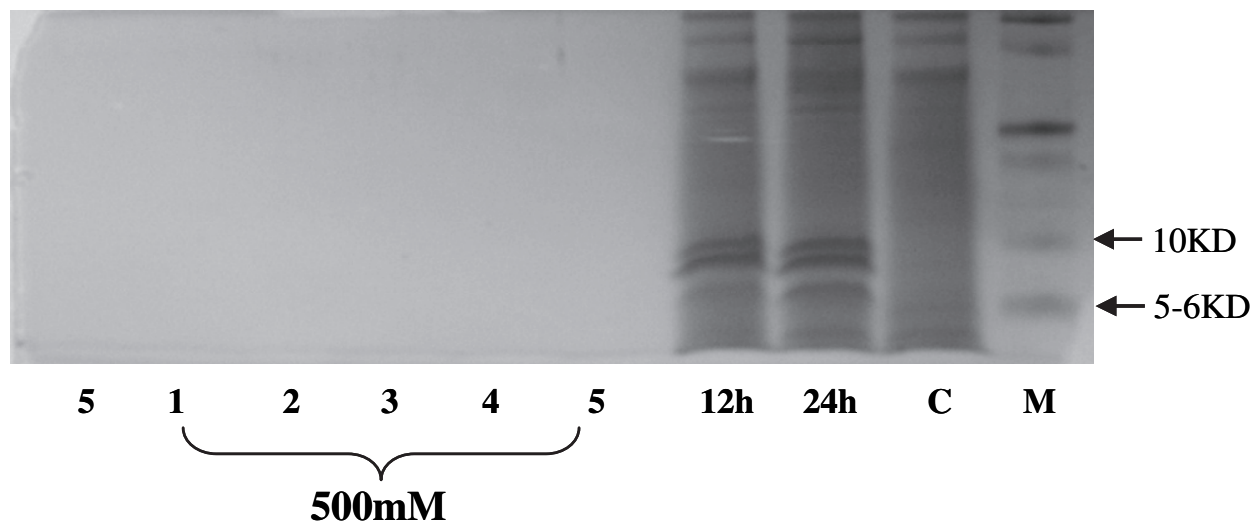

Fig. 11. Isolation and purification of TiNPY1 by His $\bullet$ Bind Column. TiNPY1 secreted by pPICZaA-TiNPY1-X-33 were isolated by His $\bullet$ Bind Column, and then were eluted by different concentration of imidazole $(150 \mathrm{mM}, 250 \mathrm{mM}$ and $500 \mathrm{mM})$. M: protein Marker; C: yeast culture supernatant flowing through His $\bullet$ Bind column; $12 \mathrm{~h}$ and $24 \mathrm{~h}$ : yeast culture supernatant induct for 12 and 24 hours.

After 50 days' feeding experiment, food consumptions in group 1 ( $0.15 \mu g$ TiNPY1/g feed), 2

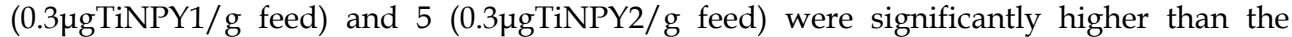
control group by $18.03 \%(\mathrm{P}<0.01), 20.80 \%(\mathrm{P}<0.01)$ and $30.22 \%(\mathrm{P}<0.001)$ respectively, but there was no obvious difference between group3 $(0.6 \mu \mathrm{gTiNPY} 1 / \mathrm{g}$ feed) and control group 
(table 1). Consistent with the results of food consumption, feed conversion ratio (SGR) of group1 (1.72 \pm 0.017$)$, group2 $(1.73 \pm 0.017)$ and group5 $(1.73 \pm 0.031)$ were significantly lower than the control group which with a FCR of $1.89 \pm 0.02$. Again, no apparent distinction was observed between group 3 and control group in FCR (Table 1 and Fig 14)

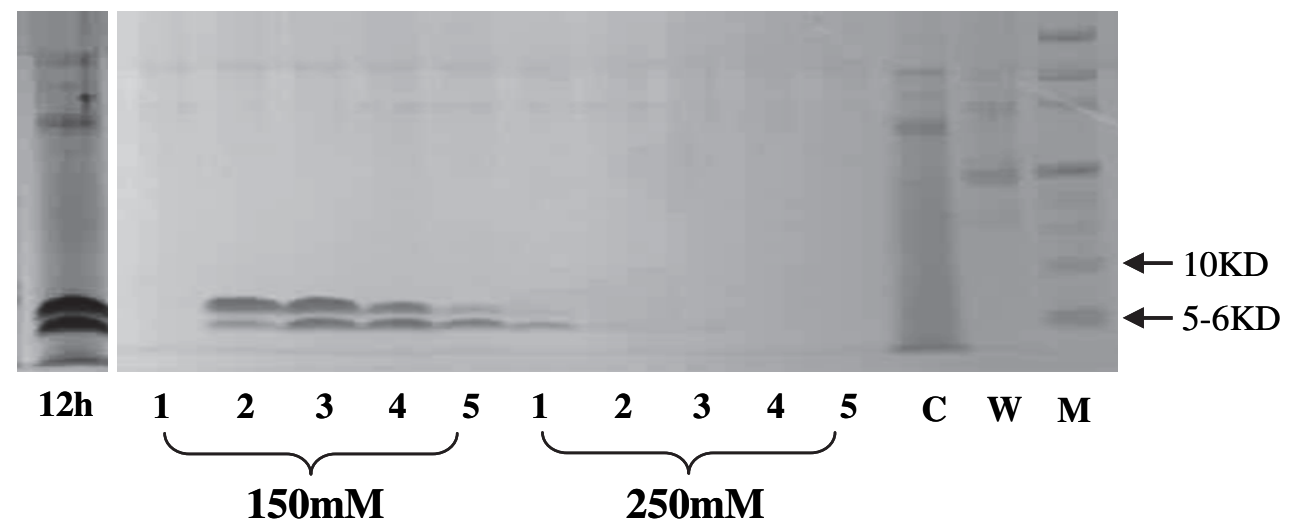

Fig. 12. Isolation and purification of TiNPY2 by His $\bullet$ Bind Column. TiNPY2 secreted by pPICZaA-TiNPY2-X-33 were isolated by His •Bind Column, and then eluted by different concentration of imidazole $(150 \mathrm{mM}, 250 \mathrm{mM})$. M: protein Marker; C: yeast culture supernatant flowing through His $\bullet$ Bind column; W: washing buffer. $12 \mathrm{~h}$ : yeast culture supernatant induced for 12 hour.

\begin{tabular}{|l|c|c|c|c|c|}
\hline Treatment & Group 1 & Group 2 & Group 3 & Group 4 & Group 5 \\
\hline Initial MBW(g) & $72.94 \pm 0.49^{\mathrm{a}}$ & $72.88 \pm 0.11^{\mathrm{a}}$ & $73.03 \pm 0.30^{\mathrm{a}}$ & $73.69 \pm 0.41^{\mathrm{a}}$ & $72.94 \pm 0.27^{\mathrm{a}}$ \\
\hline Final MBW(g) & $181.78 \pm 1.77^{\mathrm{c}}$ & $183.80 \pm 2.56^{\mathrm{c}}$ & $167.56 \pm 6.12^{\mathrm{a}}$ & $157.64 \pm 2.64^{\mathrm{a}}$ & $193.04 \pm 3.82^{\mathrm{c}}$ \\
\hline Initial MBL(cm) & $13.01 \pm 0.06^{\mathrm{a}}$ & $13.00 \pm 0.01^{\mathrm{a}}$ & $12.99 \pm 0.06^{\mathrm{a}}$ & $13.04 \pm 0.07^{\mathrm{a}}$ & $13.00 \pm 0.07^{\mathrm{a}}$ \\
\hline Final MBL(cm) & $17.45 \pm 0.10^{\mathrm{bc}}$ & $17.69 \pm 0.07^{\mathrm{c}}$ & $17.32 \pm 0.10^{\mathrm{b}}$ & $17.02 \pm 0.11^{\mathrm{a}}$ & $17.69 \pm 0.07^{\mathrm{c}}$ \\
\hline SGR & $1.83 \pm 0.023^{\mathrm{c}}$ & $1.85 \pm 0.027^{\mathrm{c}}$ & $1.66 \pm 0.075^{\mathrm{b}}$ & $1.52 \pm 0.037^{\mathrm{a}}$ & $1.95 \pm 0.036^{\mathrm{c}}$ \\
\hline Feed comsuption(g) & $187.84 \pm 3.32^{\mathrm{bc}}$ & $192.26 \pm 4.91^{\mathrm{c}}$ & $174.13 \pm 5.26^{\mathrm{b}}$ & $159.15 \pm 6.45^{\mathrm{a}}$ & $207.24 \pm 2.94^{\mathrm{c}}$ \\
\hline FCR & $1.72 \pm 0.017^{\mathrm{b}}$ & $1.73 \pm 0.017^{\mathrm{b}}$ & $1.85 \pm 0.065^{\mathrm{a}}$ & $1.89 \pm 0.020^{\mathrm{a}}$ & $1.73 \pm 0.031^{\mathrm{b}}$ \\
\hline HSI & $2.92 \pm 0.088^{\mathrm{a}}$ & $2.76 \pm 0.072^{\mathrm{a}}$ & $2.85 \pm 0.103^{\mathrm{a}}$ & $2.90 \pm 0.101^{\mathrm{a}}$ & $2.81 \pm 0.080^{\mathrm{a}}$ \\
\hline Gut weight ratio & $7.61 \pm 0.27^{\mathrm{a}}$ & $7.61 \pm 0.26^{\mathrm{a}}$ & $7.58 \pm 0.20^{\mathrm{a}}$ & $7.74 \pm 0.23^{\mathrm{a}}$ & $7.71 \pm 0.07^{\mathrm{a}}$ \\
\hline
\end{tabular}

Table 1. Summary of the indexes related to the growth and feeding of tilapia treated with TiNPY1 and TiNPY2. Values are means \pm SEM of three replicates, $n=12$ per replicate. Values with different superscripts are significantly different from each other (b indicated $\mathrm{P}<0.05$ or $c$ indicated $\mathrm{P}<0.001)$. MBW means body weight; MBL means body length; SGR $(\% / \mathrm{d})=$ $(\ln W t-\ln W 0) / \mathrm{d} \times 100$, Wt: final weights $(\mathrm{g})$, W0: initial weights $(\mathrm{g})$, d: experimental days; FCR = feed consumption (g)/fish weight gain (g); HIS=liver weight (g)/ body weight (g); gut weight ratio= gut weight $(\mathrm{g}) /$ body weight $(\mathrm{g})$. Group 1, 2, 3 were fed with $0.15,0.3$, $0.6 \mu \mathrm{gTiNPY} 1 / \mathrm{g}$ feed; Group 4 fed with negative control diet; group 5 fed with $0.3 \mu$ gTiNPY2/g feed. 


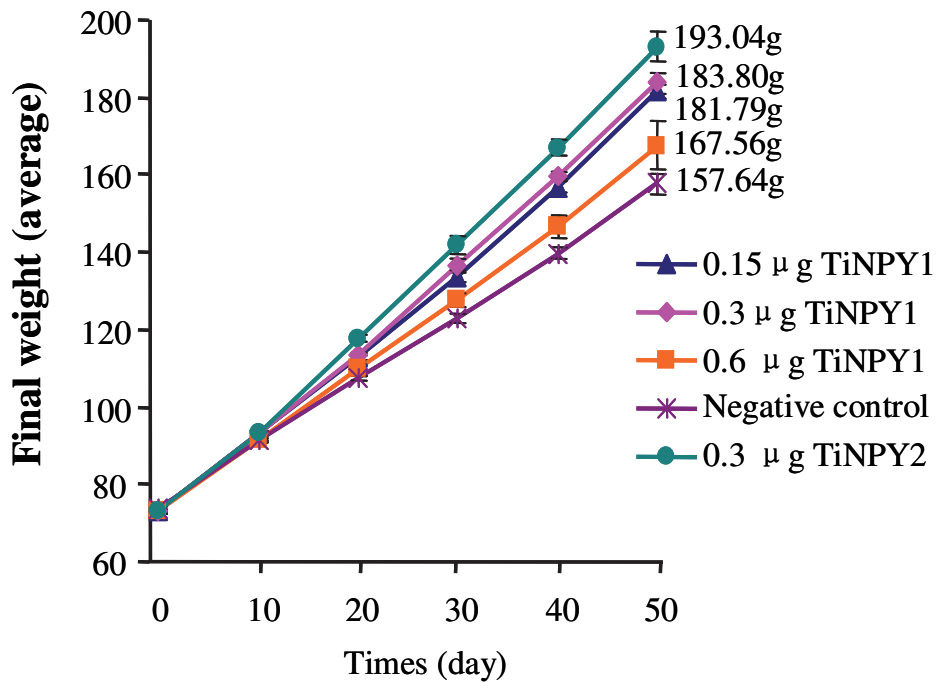

Fig. 13. Average individual body weight of tilapia fed with TiNPY1 or TiNPY2 in different days. Values are means \pm SEM of three replicates $(n=12$ per replicate). The group fed with control diet acts as negative control.

\begin{tabular}{|l|c|c|c|c|c|}
\hline Index & Group 1 & Group 2 & Group 3 & Group 4 & Group 5 \\
\hline Water (\%) & $76.40 \pm 0.31^{\mathrm{a}}$ & $76.56 \pm 0.21^{\mathrm{a}}$ & $76.34 \pm 0.20^{\mathrm{a}}$ & $76.29 \pm 0.037^{\mathrm{a}}$ & $76.48 \pm 0.20^{\mathrm{a}}$ \\
\hline Protein (\%) & $21.10 \pm 0.36^{\mathrm{a}}$ & $21.06 \pm 0.27^{\mathrm{a}}$ & $21.15 \pm 0.15^{\mathrm{a}}$ & $21.17 \pm 0.09^{\mathrm{a}}$ & $21.11 \pm 0.13^{\mathrm{a}}$ \\
\hline Lipid (\%) & $0.84 \pm 0.05^{\mathrm{ab}}$ & $0.88 \pm 0.06^{\mathrm{ab}}$ & $0.82 \pm 0.12^{\mathrm{ab}}$ & $0.72 \pm 0.12^{\mathrm{a}}$ & $0.98 \pm 0.05^{\mathrm{b}}$ \\
\hline Ash (\%) & $1.35 \pm 0.05^{\mathrm{a}}$ & $1.35 \pm 0.01^{\mathrm{a}}$ & $1.36 \pm 0.02^{\mathrm{a}}$ & $1.41 \pm 0.07^{\mathrm{a}}$ & $1.33 \pm 0.04^{\mathrm{a}}$ \\
\hline
\end{tabular}

Table 2. White muscle composition of tilapia fed with TiNPY1 and TiNPY2 after 50 days. Values are means \pm SEM of three replicates $(n=12$ per replicate). Values with different superscripts are significantly different from each other $(\mathrm{P}<0.05)$. Group $1,2,3$ were fed with $0.15,0.3,0.6 \mu g$ TiNPY1/g feed, respectively; Group 4 was fed with control diet and acts as a negative control. Group 5 was fed with $0.3 \mu \mathrm{gTiNPY} 2 / \mathrm{g}$ feed.

\subsection{Regulation of recombinant TiNPY on mRNA expressions of growth hormone, NPY and orexin in GIFT tilapia}

Using real-time PCR technique, the effects of recombinant TiNPY on mRNA expressions of GH, NPY and orexin of tilapia were investigated. The results showed that $0.3 \mu$ gTiNPY2/g feed could significantly stimulate pituitary GH mRNA expression. In contrast to TiNPY2, 0.15 and $0.3 \mu \mathrm{gTiNPY} 1 / \mathrm{g}$ feed obviously inhibited GH mRNA expression and $0.6 \mu \mathrm{gTiNPY} 1 / \mathrm{g}$ feed showed no effect on GH mRNA level (Fig.15).NPY and orexin are potent stimulators of food intake in teleosts and mainly expressed in hypothalamus of vertebrates. In this experiment, our study showed that $0.3 \mu \mathrm{gTiNPY} 2 / \mathrm{g}$ feed significantly reduced mRNA expression of NPY as well as orexin and only $0.15 \mu \mathrm{gTiNPY} 1 / \mathrm{g}$ feed has

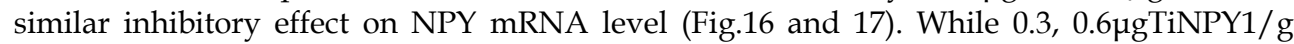
feed showed no effect on NPY mRNA expression (Fig.16) and all treatments of TiNPY1 haven't any obvious effect on orexin mRNA level (Fig.17). 


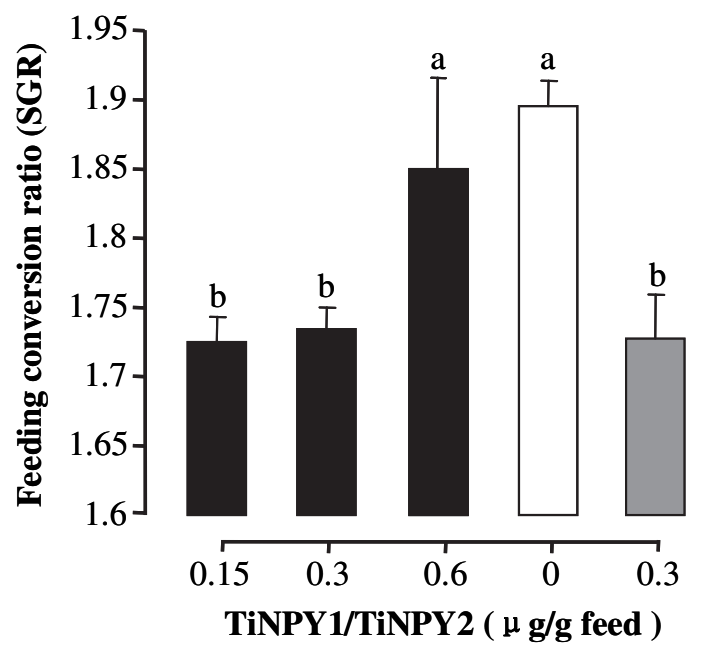

Fig. 14. Average feed conversion ratio (FCR) of tilapia fed with TiNPY1 $(0.15,0.3$ and $0.6 \mu \mathrm{g} / \mathrm{g}$ feed, black columns) and TiNPY2 (0.3 $\mu \mathrm{g} / \mathrm{g}$ feed, grey column) after 50 days. The group fed with control diet acts as negative control (white column). Values presented are expressed as means \pm SEM of three replicates ( $n=12$ per replicate) and groups denoted by different letters represent a significant difference at $\mathrm{P}<0.05$ (ANOVA followed by Fisher's LSD test).

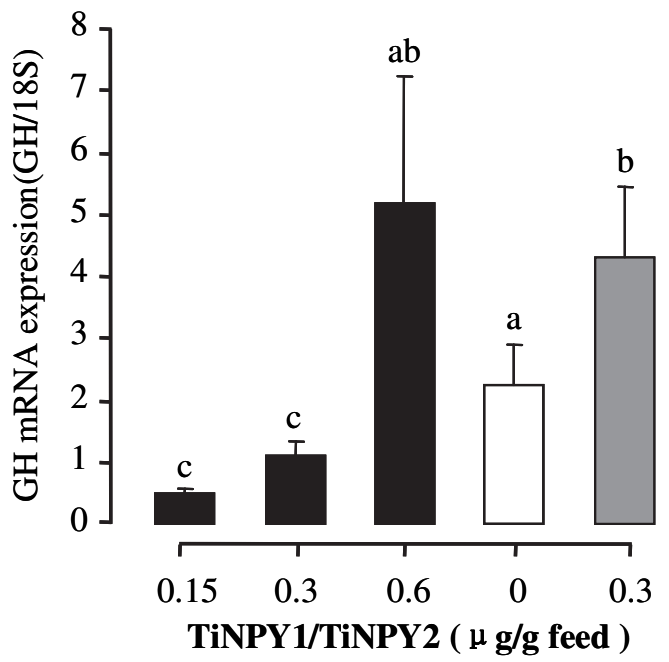

Fig. 15. Growth hormone (GH) mRNA expression of tilapia fed with TiNPY1 $(0.15,0.3$ and $0.6 \mu \mathrm{g} / \mathrm{g}$ feed, black columns) or TiNPY2 $(0.3 \mu \mathrm{g} / \mathrm{g}$ feed, grey column) after 50 days. The pituitaries of tilapia were homogenized for RNA extraction and RT-PCR. Then, Real-time PCR was used to detect the expression level of GH. The group fed with control diet acts as negative control (white column). Values presented are expressed as means \pm SEM of three replicates $(n=12$ per replicate) and groups denoted by different letters represent a significant difference at $\mathrm{P}<0.05$ (ANOVA followed by Fisher's LSD test). 


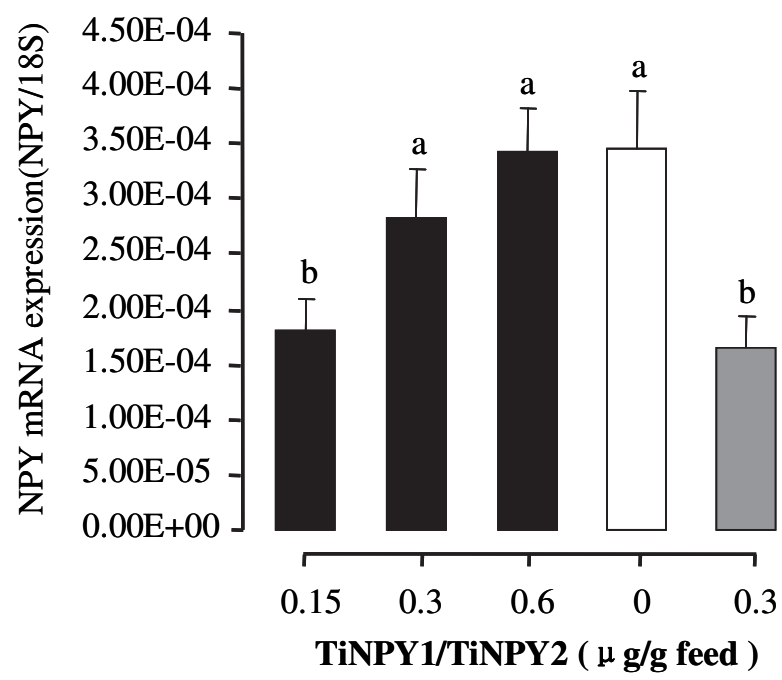

Fig. 16. NPY mRNA expression of tilapia fed with TiNPY1 $(0.15,0.3$ and $0.6 \mu \mathrm{g} / \mathrm{g}$ feed, black columns) or TiNPY2 (0.3 $\mu \mathrm{g} / \mathrm{g}$ feed, grey column) after 50 days. The hypothalamuses of tilapia were homogenized for RNA extraction and RT-PCR. Then, Real-time PCR was used to detect the expression level of NPY. The group fed with control diet acts as negative control (white column). Values presented are expressed as means \pm SEM of three replicates $(n=12$ per replicate) and groups denoted by different letters represent a significant difference at $\mathrm{P}<0.05$ (ANOVA followed by Fisher's LSD test).

\section{Discussion}

Regulation of food intake is very important for the survival and growth of animals. As in mammals, NPY is also the most potent orexigenic peptide in fish (Matsuda, 2009; Volkoff, 2006; Volkoff et al., 2005). GIFT tilapia is a hybrid of Nile tilapia (Oreochromis niloticus) and it is a major fish species widely used in aquaculture of China. As the first step to study the functions of recombinant NPY protein in food intake regulation of GIFT tilapia, a cDNA for GIFT tilapia NPY was isolated by molecular cloning. The deduced a.a. sequence of GIFT tilapia NPY revealed that this peptide is the precursor of NPY that comprises the signal peptide, a region coding for the 36 a.a. mature peptide and a C-terminal domain. Sequence alignment of amino acids showed that the NPY mature peptide of GIFT tilapia is the identity of that red tilapia (GenBank: AAV49168) and highly homologous to human NPY with the identity of $86 \%$. This result again clearly proved that NPY is the most highly conserved neuropeptide in vertebrates(Blomqvist et al., 1992).

In the study of protein function, E. coli is commonly used to express large quantities of protein. However, there are several obvious deficiencies exists in the E. coli expression system. Firstly, the recombinant proteins expressed using this system are intracellular types and are easy to form inclusion bodies of expressions. Secondly, the system lacks post- 


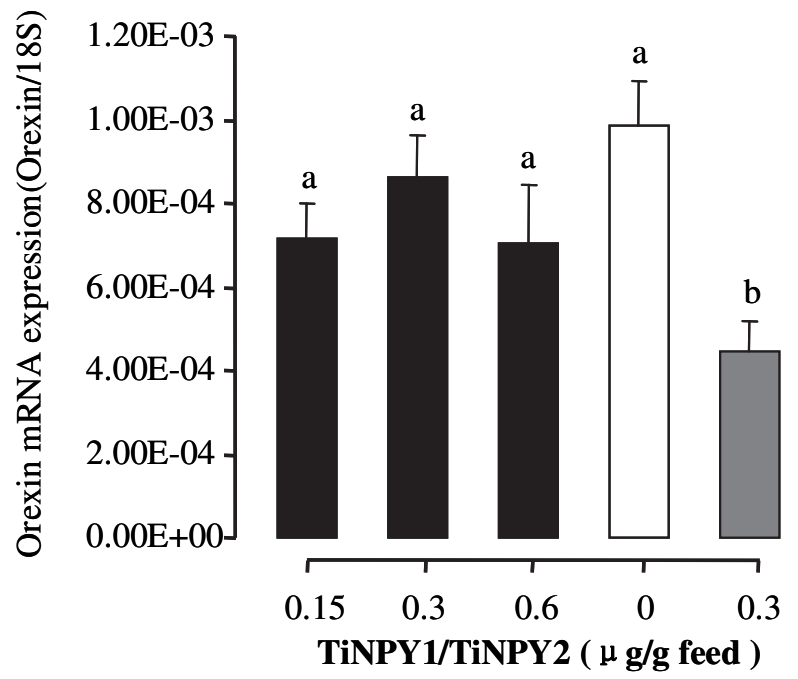

Fig. 17. Orexin mRNA expression of tilapia fed with TiNPY1 $(0.15,0.3$ and $0.6 \mu \mathrm{g} / \mathrm{g}$ feed, black columns) or TiNPY2 $(0.3 \mu \mathrm{g} / \mathrm{g}$ feed, grey column) after 50 days. The hypothalamuses of tilapia were homogenized for RNA extraction and RT-PCR. Then, Real-time PCR was used to detect the expression level of orexin. The group fed with control diet acts as negative control (white column). Values presented are expressed as means \pm SEM of three replicates $(n=12$ per replicate) and groups denoted by different letters represent a significant difference at $\mathrm{P}<0.05$ (ANOVA followed by Fisher's LSD test).

translational modification for foreign proteins. Thirdly, the immunogenic sources of E. coli such as exotoxin are often mixed with the products during cell fragmentation. Moreover, $E$. coli itself is an important source of water contamination. Therefore, these deficiencies limit its application in protein expression studies. As a eukaryote, yeast Pichia pastoris, a useful system for the expression of milligram-to-gram quantities of proteins for both basic laboratory research and industrial manufacture, owns advantages of higher eukaryotic expression systems such as protein processing, protein folding, and posttranslational modification, while being as easy to manipulate as E. coli or Saccharomyces cerevisiae (Carpio et al., 2009; Cregg et al., 2000).

Expression of target protein in Pichia pastoris can be either intracellular or secreted, and secretion requires a signal sequence on the expressed protein to target it to the secretory pathway. Although several different secretion signals have been used successfully, including the native signal peptide of the heterologous proteins, the secretion signal sequence from the Saccharomyces cerevisiae a factor prepro-peptide has been used with the most success(Cregg et al., 2000). The major advantage of expressing heterologous proteins as secreted proteins is that Pichia pastoris secretes very low levels of native proteins (Cregg et al., 2000), which facilitates the purification and acquisition of a large scale recombinant heterologous proteins. Additionally, it has recently been demonstrated that the culture 
supernatant proteins of $P$. pastoris can have beneficial effects on fish larval growth and innate immunity (Carpio et al., 2009). These characteristics make P. pastoris a very useful heterologous proteins expression system in production of recombinant proteins for aquaculture purposes. The processing of the a-factor mating signal sequence in pPICZa occurs in two steps: the preliminary cleavage of the signal sequence by the KEX2 gene product, with the final Kex2 cleavage occurring between arginine and glutamine in the sequence Glu-Lys-Arg * Glu-Ala-Glu-Ala, where * is the site of cleavage; and the Glu-Ala repeats are further cleaved by the STE13 gene product (user manual of EasySelect ${ }^{\mathrm{TM}}$ Pichia Expression Kit, Catalog no. K1740-01).

After obtained the ORF of GIFT tilapia NPY, two recombinant Pichia X-33 stains of PICZaA-TiNPY1 and pPICZaA-TiNPY2 were established and they can efficiently express recombinant TiNPY1 and TiNPY2, respectively. The two recombinant proteins were supposed to be expressed homogenously with no glycosylation, and comprise only one protein band in Tricine-SDS-PAGE and western blot analysis, respectively. However, three bands with different molecular weight of each recombinant NPY were observed after methanol induction for more than 12 hours, and all of them could be isolated and purified by Ni-NTA His $\bullet$ Bind Column, which means all of them conjugated with $6 \times$ His tag designed in our study. Interestingly, only the upper two bands (with larger molecular weight) could be recognized by rabbit polyclonal antibody against porcine NPY. Our hypothesis is that the N-terminal signal peptide from the a factor was not completely cut off and Glu-Ala repeats were left on the N-terminus of the expressed protein of the first band (with largest molecular weight), the second band contained mainly recombinant protein with native N-terminus of tilapia NPY; and the third band, with a smallest molecular weight and couldn't be recognized by NPY antibody, was the degradation of recombinant NPY with the degradation of native N-terminus and the preservation of Cterminus. This speculation was verified by N-terminal a. a. sequence with Edman stepwise degradation.

Oral delivery of peptide and protein has been proved to be the most suitable route and least intrusive for delivery to fish in the aquaculture industry (Kiris GA, 2007; Ledger et al., 2002). As mentioned above, NPY is the most important factor in regulating food intake and energy metabolism in vertebrates. To test the physiological functions of recombinant TiNPY and TiNPY2 of GIFT tilapia, yeast culture supernatants with different dosages of the two proteins were directly sprayed on the surface of ordinary commercial extruded floating feed and acts as daily diets to feed to the juvenile tilapia. As expected, both TiNPY1 and TiNPY2 could significantly stimulate the food intake of juvenile tilapia. Compared to the control group, the food intake of tilapia fed with 0.15 or $0.3 \mu \mathrm{gTiNPY} 1 / \mathrm{g}$ feed, or fed with $0.3 \mu \mathrm{gTiNPY} 2 / \mathrm{g}$ feed was increased to $18.03 \%, 20.80 \%$ and $30.22 \%$, respectively. This result demonstrated again that NPY does not lose its feeding stimulatory effect when passed through the alimentary canal of fish as was found in the red tilapia (Kiris GA, 2007). Similar stimulated food intake results were found when Juvenile tilapia received intraperitoneal injection of recombinant neuropeptide $\mathrm{Y}$ expressed by Escherichia coli $(1 \mu \mathrm{g} / \mathrm{g}$ of body weight) (Carpio et al., 2006), or i.p. injection $(0.6 \mu \mathrm{g} / \mathrm{g}$ of body weight) or orally given $(0.25$ $\mu \mathrm{g} / \mathrm{g}$ of feed) of human NPY (Kiris GA, 2007). And this result is also highly consistent with those reported in other fish species. For example, injections of mammal NPY or fish NPY promoted food intake of goldfish (Narnaware et al., 2000; Peng et al., 1993a) and rainbow 
trout (Aldegunde and Mancebo, 2006). Moreover, our study also showed that the FCRs of tilapia fed with 0.15 or $0.3 \mu \mathrm{g} / \mathrm{g}$ feed of TiNPY1 and fed with $0.3 \mu \mathrm{g} / \mathrm{g}$ feed of TiNPY2 were significantly lower than the control group, which perhaps suggests some significance in the aquaculture of tilapia. However, FCR was not altered in tilapia treated with recombinant NPY expressed by Escherichia coli (1 $\mu \mathrm{g} / \mathrm{g}$ of body weight) (Carpio et al., 2006).

More food intake and low FCR often lead to faster growth. In the present study, the percentage of weight gain in the tilapia fed with $0.15 \mu \mathrm{g} / \mathrm{g}$ feed, $0.3 \mu \mathrm{g} / \mathrm{g}$ feed or $0.6 \mu \mathrm{g} / \mathrm{g}$ feed of recombinant TiNPY1 were $29.65 \%, 32.11 \%$ or $12.60 \%$ respectively higher than the control group, which was fed with the control diet. The feed with $0.3 \mu$ TTiNPY2/g feed made the highest growth speed, with a mean body weight gain of $43.05 \%$ higher than the control group. The similar fasted growth results were found in other studies. NPY injection significantly induced energy consumption and body weight of goldfish (Narnaware and Peter, 2001a; Narnaware and Peter, 2001b) and tilapia (Carpio et al., 2006; Kiris GA, 2007); 18 and 30 days after immersion baths with recombinant NPY expressed by Escherichia coli three times a week, body weight and body length of catfish were significantly higher than the control (Carpio Y, 2007); Both injection and oral administration with human NPY significantly promoted the growth and body weight of tilapia(Kiris GA, 2007).

The effect of NPY on food intake and growth seems dosage and species specific and too high or too low dosage could not elevate food intake in fish and shrimp (Kiris GA, 2007; Narnaware and Peter, 2001b), The growth and food intake of tilapia Oreochromis niloticus were both significantly higher at dosage of $0.25 \mu \mathrm{g} / \mathrm{g}$ feed compared to the control, but lower dosage of $0.125 \mu \mathrm{g} / \mathrm{g}$ feed only stimulated food intake(Kiris GA, 2007); Although the group of red tilapia injected with $0.1 \mathrm{mg} / \mathrm{gbw}$ of recombinant NPY showed a weight increase of $26 \%$ when compared to the control group, it is still not statistically significant (Carpio et al., 2006). In our study, weight increase of tilapia fed with a dosage of $0.6 \mu \mathrm{gTiNPY} 1 / \mathrm{g}$ feed was $12.60 \%$ higher than control, but with no statistical significance, and significantly lower than fish fed with lower dosages of 0.15 and 0.3 TiNPY1 $\mu$ g/g feed. The tilapia fed with $0.3 \mu \mathrm{g}$ TiNPY2/g feed obtained the fastest growth rate compared with groups fed with TiNPY1 and the control diet.

Some studies have reported that NPY is involved in the neuroendocrine regulation of growth hormone. For example, NPY stimulates GH secretion in vitro and in vivo in goldfish (Peng et al., 1993b; Peng et al., 1993a) and catfish (Mazumdar et al., 2006). Similar as in mammals, NPY also interacts with a number of appetite factors, e.g. orexin, leptin and CART, to regulate food intake in fish (Volkoff, 2006; Volkoff et al., 2005). In the present study, we also investigated the effects of recombinant proteins of TiNPY1 and TiNPY2 on mRNA expressions of GH in pituitary and NPY as well as orexin in hypothalamus. The results showed that TiNPY2 $(0.3 \mu \mathrm{g} / \mathrm{g}$ feed) significantly induced GH mRNA expression. In contrast to TiNPY2, low dosages of TiNPY1 $(0.15$ and $0.3 \mu \mathrm{g} / \mathrm{g}$ feed $)$ obviously inhibited GH mRNA expression and high dosage of TiNPY1 $(0.6 \mu \mathrm{g} / \mathrm{g}$ feed) showed no effect on GH mRNA level. For NPY and orexin, the same dosage of TiNPY2 significantly inhibited mRNA expression of NPY as well as orexin to $50 \%$ compared to the control group and only $0.15 \mu \mathrm{g}$ TiNPY1/g feed has similar inhibitory effect on NPY mRNA level. In contrast, 0.3 and $0.6 \mu \mathrm{gTiNPY} 1 / \mathrm{g}$ feed showed no effect on NPY mRNA expression and all treatments of TiNPY1 haven't any obvious effect on orexin mRNA level. These results, taken together, suggested that long-term feeding of tilapia with recombinant NPY proteins could up- 
regulate GH mRNA expression and down-regulate the gene expressions of NPY and orexin. Further experiments are needed to test our hypothesis. In the whole experiment, we noticed that the effects of recombinant protein of TiNPY2 are much significant than that induced by TiNPY1. As the two forms of recombinant tilapia NPY expressed by yeast are only different in conjugated tags for identification and purification. The conjugated tag of TiNPY1, which was added a sequence with the molecular weight of $2.2 \mathrm{KD}$ to the recombinant protein, contains c-myc, 6× His tag and the amino-acid residues between them. While, the conjugated tag of TiNPY2, which was added to a sequence with the molecular weight of $0.8 \mathrm{KDa}$ to the recombinant protein, only contains six amino-acid residues of $6 \times$ His. The difference of their effects on the food intake and mRNA expression of GH, NPY and orexin may come from the difference of the conjugated tag attached with them .These results perhaps indicated that a larger conjugated tag of recombinant NPY would interfere its absorption or transportation across the blood-brain barrier. The function of recombinant NPY were also perhaps disturbed by the tags, as lipid content of the white muscle was higher in tilapia fed with TiNPY2 than those feed with TiNPY1 or control diet.

\section{Conclusion}

We obtained the cDNA encoding the precursor of NPY from GIFT tilapia. The deduced amino acids sequence of the mature peptide of GIFT tilapia is the same as that of red tilapia and it is highly conserved with human NPY. Two Pichia X-33 stains of PICZaA-TiNPY1 and pPICZaA-TiNPY2 were established and they can express the recombinant proteins of TiNPY1 and TiNPY2, respectively. Long-term feeding tilapia with TiNPY1 and TiNPY2 could significantly stimulate the food intake and growth of tilapia and at the same time to reduce the feeding conversion ratio of feed. Moreover, TiNPY2 can induce GH mRNA expression in the pituitary of tilapia and while potently suppressed mRNA expressions of hypothalamic NPY and orexin. For TiNPY1, lower dosages of which could inhibit GH and NPY mRNA expression. All dosages of TiNPY1 used in our experiment showed no effect on orexin mRNA expression. The present study clearly demonstrated that the recombinant protein of NPY expressed from the yeast Pichia pastoris has biological activity and oral delivery of NPY is a useful method in the aquaculture industry.

\section{Acknowledgment}

This work was supported by the National Basic Research Program (2010CB126302), the China Agriculture Research System (CARS-49), the Agriculture Research Special Funds of 349, the National High Technology Research Program (2007AA10Z165) and the Fundamental Research Funds for the Central Universities awarded to Professor Wensheng Li.

\section{References}

Aldegunde, M., Mancebo, M., (2006). Effects of neuropeptide $Y$ on food intake and brain biogenic amines in the rainbow trout (Oncorhynchus mykiss). Peptides. 27, 71927. 
Blomqvist, A. G., et al., (1992). Strong evolutionary conservation of neuropeptide Y: sequences of chicken, goldfish, and Torpedo marmorata DNA clones. Proc Natl Acad Sci U S A. 89, 2350-4.

Carpio, Y., et al., (2006). Cloning, expression and growth promoting action of Red tilapia (Oreochromis sp.) neuropeptide Y. Peptides. 27, 710-8.

Carpio, Y., et al., (2009). Regulation of body mass growth through activin type IIB receptor in teleost fish. Gen Comp Endocrinol. 160, 158-67.

Carpio Y, L. K., Acosta J, Morales R, Estrada MP., (2007). Recombinant tilapia Neuropeptide $Y$ promotes growth and antioxidant defenses in African catfish (Clarias gariepinus) fry. . Aquaculture 272 649-655.

Cerda-Reverter, J. M., Larhammar, D., (2000a). Neuropeptide Y family of peptides: structure, anatomical expression, function, and molecular evolution. Biochem Cell Biol. 78, 371-92.

Cerda-Reverter, J. M., et al., (2000b). Molecular evolution of the neuropeptide Y (NPY) family of peptides: cloning of three NPY-related peptides from the sea bass (Dicentrarchus labrax). Regul Pept. 95, 25-34.

Chavez, M., et al., (1998). Effect of a high-fat diet on food intake and hypothalamic neuropeptide gene expression in streptozotocin diabetes. J Clin Invest. 102, 3406.

Cregg, J. M., et al., (2000). Recombinant protein expression in Pichia pastoris. Mol Biotechnol. 16, 23-52.

Faber, K. N., et al., (1995). Review: methylotrophic yeasts as factories for the production of foreign proteins. Yeast. 11, 1331-44.

Gelineau, A., Boujard, T., (2001). Oral administration of cholecystokinin receptor antagonists increase feed intake in rainbow trout. J. Fish Biol. . 58, 716-724.

Halford, J. C., et al., (2004). The pharmacology of human appetite expression. Curr Drug Targets. 5, 221-40.

Kalra, S. P., et al., (1999). Interacting appetite-regulating pathways in the hypothalamic regulation of body weight. Endocr Rev. 20, 68-100.

Kehoe, A. S., Volkoff, H., (2007). Cloning and characterization of neuropeptide Y (NPY) and cocaine and amphetamine regulated transcript (CART) in Atlantic cod (Gadus morhua). Comp Biochem Physiol A Mol Integr Physiol. 146, 451-61.

Kiris GA, K. M., Dikel S., (2007). Stimulatory effects of neuropeptide Y on food intake and growth of Oreochromis niloticus. Aquaculture. 264, 383-389.

Ledger, R., et al., (2002). The metabolic barrier of the lower intestinal tract of salmon to the oral delivery of protein and peptide drugs. J Control Release. 85, 91-103.

Lin, S., et al., (2004). NPY and Y receptors: lessons from transgenic and knockout models. Neuropeptides. 38, 189-200.

Lopez-Patino, M. A., et al., (1999). Neuropeptide $\mathrm{Y}$ has a stimulatory action on feeding behavior in goldfish (Carassius auratus). Eur J Pharmacol. 377, 147-53.

Matsuda, K., (2009). Recent advances in the regulation of feeding behavior by neuropeptides in fish. Ann N Y Acad Sci. 1163, 241-50. 
Mazumdar, M., et al., (2006). Involvement of neuropeptide $Y$ Y1 receptors in the regulation of $\mathrm{LH}$ and $\mathrm{GH}$ cells in the pituitary of the catfish, Clarias batrachus: an immunocytochemical study. Gen Comp Endocrinol. 149, 190-6.

Narnaware, Y. K., Peter, R. E., (2001a). Effects of food deprivation and refeeding on neuropeptide Y (NPY) mRNA levels in goldfish. Comp Biochem Physiol B Biochem Mol Biol. 129, 633-7.

Narnaware, Y. K., Peter, R. E., (2001b). Neuropeptide Y stimulates food consumption through multiple receptors in goldfish. Physiol Behav. 74, 185-90.

Narnaware, Y. K., Peter, R. E., (2002). Influence of diet composition on food intake and neuropeptide Y (NPY) gene expression in goldfish brain. Regul Pept. 103, 7583.

Narnaware, Y. K., et al., (2000). Regulation of food intake by neuropeptide Y in goldfish. Am J Physiol Regul Integr Comp Physiol. 279, R1025-34.

Pedrazzini, T., (2004). Importance of NPY Y1 receptor-mediated pathways: assessment using NPY Y1 receptor knockouts. Neuropeptides. 38, 267-75.

Pedrazzini, T., et al., (2003). Neuropeptide Y: the universal soldier. Cell Mol Life Sci. 60, 35077.

Peng, C., et al., (1993b). Neuropeptide-Y stimulates growth hormone and gonadotropin-II secretion in the goldfish pituitary: involvement of both presynaptic and pituitary cell actions. Endocrinology. 132, 1820-9.

Peng, C., et al., (1993a). Actions of goldfish neuropeptide $Y$ on the secretion of growth hormone and gonadotropin-II in female goldfish. Gen Comp Endocrinol. 90, 30617.

Romanos, M. A., et al., (1992). Foreign gene expression in yeast: a review. Yeast. 8, 42388.

Sundstrom, G., et al., (2005). Ray-fin fish tetraploidization gave rise to pufferfish duplicates of NPY and PYY, but zebrafish NPY duplicate was lost. Ann N Y Acad Sci. 1040, 476-8.

Sundstrom, G., et al., (2008). Evolution of the neuropeptide $\mathrm{Y}$ family: new genes by chromosome duplications in early vertebrates and in teleost fishes. Gen Comp Endocrinol. 155, 705-16.

Tatemoto, K., et al., (1982). Neuropeptide Y--a novel brain peptide with structural similarities to peptide YY and pancreatic polypeptide. Nature. 296, 659-60.

Valassi, E., et al., (2008). Neuroendocrine control of food intake. Nutr Metab Cardiovasc Dis. $18,158-68$.

Volkoff, H., (2006). The role of neuropeptide Y, orexins, cocaine and amphetamine-related transcript, cholecystokinin, amylin and leptin in the regulation of feeding in fish. Comp Biochem Physiol A Mol Integr Physiol. 144, 325-31.

Volkoff, H., et al., (2005). Neuropeptides and the control of food intake in fish. Gen Comp Endocrinol. 142, 3-19.

Volkoff, H., et al., (2010). Influence of intrinsic signals and environmental cues on the endocrine control of feeding in fish: potential application in aquaculture. Gen Comp Endocrinol. 167, 352-9. 
Woods, S. C., et al., (1998). NPY and food intake: discrepancies in the model. Regul Pept. 7576, 403-8. 


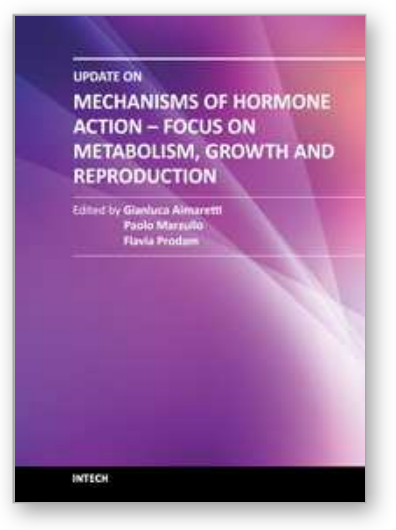

\section{Update on Mechanisms of Hormone Action - Focus on Metabolism, Growth and Reproduction}

Edited by Prof. Gianluca Aimaretti

ISBN 978-953-307-341-5

Hard cover, 470 pages

Publisher InTech

Published online 26, October, 2011

Published in print edition October, 2011

The purpose of the present volume is to focus on more recent aspects of the complex regulation of hormonal action, in particular in 3 different hot fields: metabolism, growth and reproduction. Modern approaches to the physiology and pathology of endocrine glands are based on cellular and molecular investigation of genes, peptide, hormones, protein cascade at different levels. In all of the chapters in the book all, or at least some, of these aspects are described in order to increase the endocrine knowledge.

\section{How to reference}

In order to correctly reference this scholarly work, feel free to copy and paste the following:

Guangzhong Wang, Caiyun Sun, Haoran Lin and Wensheng Li (2011). Expression of Neuropeptide Y of GIFT Tilapia (Oreochromis sp.) in Yeast Pichia Pastoris and Its Stimulatory Effects on Food Intake and Growth, Update on Mechanisms of Hormone Action - Focus on Metabolism, Growth and Reproduction, Prof. Gianluca Aimaretti (Ed.), ISBN: 978-953-307-341-5, InTech, Available from: http://www.intechopen.com/books/updateon-mechanisms-of-hormone-action-focus-on-metabolism-growth-and-reproduction/expression-ofneuropeptide-y-of-gift-tilapia-oreochromis-sp-in-yeast-pichia-pastoris-and-its-stimula

\section{INTECH}

open science | open minds

\section{InTech Europe}

University Campus STeP Ri

Slavka Krautzeka 83/A

51000 Rijeka, Croatia

Phone: +385 (51) 770447

Fax: +385 (51) 686166

www.intechopen.com

\section{InTech China}

Unit 405, Office Block, Hotel Equatorial Shanghai

No.65, Yan An Road (West), Shanghai, 200040, China

中国上海市延安西路65号上海国际贵都大饭店办公楼 405 单元

Phone: +86-21-62489820

Fax: $+86-21-62489821$ 
(C) 2011 The Author(s). Licensee IntechOpen. This is an open access article distributed under the terms of the Creative Commons Attribution 3.0 License, which permits unrestricted use, distribution, and reproduction in any medium, provided the original work is properly cited. 